\title{
EFFECTIVENESS OF NUTRIENT MANAGEMENT ON WATER QUALITY IMPROVEMENT: A SYNTHESIS ON NITRATE-NITROGEN LOSS FROM SUBSURFACE DRAINAGE
}

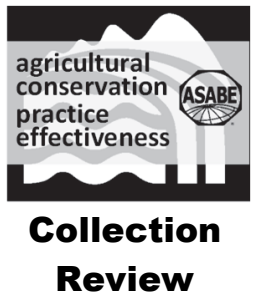

\author{
W. Liu, Y. Yuan, L. Koropeckyj-Cox
}

HighLights

- Fertilizer rate was found to be the most important factor controlling flow-weighted nitrate-N concentrations.

- Organic fertilizer may significantly increase nitrate-N losses, but $\mathrm{N}$ content of manures can be variable.

- We did not find significant differences in nitrate-N export among fertilizer application methods or timing.

- Split fertilization reduced nitrate-N export at lower fertilizer rates $\left(<167 \mathrm{~kg} \mathrm{~N} \mathrm{ha}^{-1}\right)$ but not at higher rates.

- Fertilizer $\mathrm{N}$ recommendations need re-evaluation to consider both environmental and economic effects.

\begin{abstract}
Nutrient management, as described in NRCS Code 590, has been intensively investigated, with research largely focused on crop yields and water quality. Yet, due to complex processes and mechanisms in nutrient cycling (especially the nitrogen $(N)$ cycle), there are many challenges in evaluating the effectiveness of nutrient management practices across site conditions. We therefore synthesized data from peer-reviewed publications on subsurface-drained agricultural fields in the Midwest U.S. with corn yield and drainage nitrate- $N\left(N_{3}-N\right)$ export data published from 1980 to 2019. Through literature screening and data extraction from 43 publications, we obtained 577 site-years of data with detailed information on fertilization, corn yields, precipitation, drainage volume, and drainage $\mathrm{NO}_{3}-\mathrm{N}$ load/concentration or both. In addition, we esti-

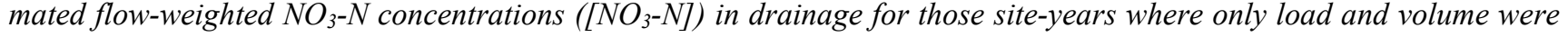
reported. Furthermore, we conducted a cost analysis using synthesized and surveyed corn yield data to evaluate the costeffectiveness of different nutrient management plans. Results from the synthesis showed that $N$ fertilizer rate was strongly positively correlated with corn yields, $\mathrm{NO}_{3}$ - $\mathrm{N}$ loads, and flow-weighted [ $\mathrm{NO}_{3}$ - $\left.\mathrm{N}\right]$. Reducing $\mathrm{N}$ fertilizer rates can effectively mitigate $\mathrm{NO}_{3}-\mathrm{N}$ losses from agricultural fields; however, our cost analysis showed negative economic returns for continuous corn production at lower $\mathrm{N}$ rates. In addition, organic fertilizers significantly boosted corn yields and $\mathrm{NO}_{3}-\mathrm{N}$ losses compared to inorganic fertilizers at comparable rates; however, accurate quantification of plant-available $N$ in organic fertilizers is necessary to guide appropriate nutrient management plans because the nutrient content may be highly variable. In terms of fertilizer application methods, we did not find significant differences in $\mathrm{NO}_{3}-\mathrm{N}$ export in drainage discharge. Lastly, impact of fertilization timing on $\mathrm{NO}_{3}$-N export varied depending on other factors such as fertilizer rate, source, and weather. According to these results, we suggest that further efforts are still required to produce effective local nutrient management plans. Furthermore, government agencies such as USDA-NRCS need to work with other agencies such as USEPA to address the potential economic losses due to implementation of lower fertilizer rates for water quality improvement.
\end{abstract}

Keywords. Conservation practice, Corn yields, Cost-effectiveness, $\mathrm{NO}_{3}-\mathrm{N}$ loss, Nutrient management, Subsurface drainage, Midwest U.S.

Submitted for review on 4 May 2020 as manuscript number NRES 14078; approved for publication as an Invited Review Article and as part of the Agricultural Conservation Practice Effectiveness Collection by the Natural Resources \& Environmental Systems Community of ASABE on 20 November 2020.

Mention of company or trade names is for description only and does not imply endorsement by the USEPA. The USEPA is an equal opportunity provider and employer.

The authors are Wenlong Liu, ORISE Postdoctoral Researcher, Yongping Yuan, Senior Research Hydrologist, and Lydia KoropeckyjCox, ORISE Fellow, USEPA Office of Research and Development, Research Triangle Park, North Carolina. Corresponding author: Yongping Yuan, 109 T. W. Alexander Dr., Research Triangle Park, NC 27711; phone: 919-541-2036; e-mail: yuan.yongping@epa.gov.
$\mathrm{T}$ This article is part of a collection that provides a systematic review and evaluation of the performance and cost-effectiveness of selected agricultural conservation practices (ACPs) on nutrient and sediment reduction.

Nutrient management (NRCS Code 590) is defined by the USDA Natural Resources Conservation Service (NRCS) as "managing rate, source, placement, and timing of plant nutrients and soil amendments while reducing environmental impacts" (NRCS, 2019). Usually, nutrient management plans are developed based on guidance from land grant universities to account for crop nutrient requirements and 
fertilizer costs. Essentially, nutrients are managed based on the 4Rs of nutrient stewardship: apply the right nutrient source with the right rate at the right time in the right place (https://www.nutrientstewardship.com/4rs; NRCS, 2019). Nutrient management is often applied with other ACPs, such as residue and tillage management, no till (NRCS Code 329) and reduced till (NRCS Code 345), conservation crop rotation (NRCS Code 328), filter strips (NRCS Code 393), cover crops (NRCS Code 340), contour farming (NRCS Code 330), and contour buffer strips (NRCS Code 332), to improve its effectiveness and/or create a comprehensive conservation plan.

Numerous field-scale and larger studies have investigated the effects of nutrient management practices on crop yields and water quality, especially nitrogen $(\mathrm{N})$ management in corn production. Corn is a leading crop in the U.S., and the most productive areas (e.g., the Midwest U.S.) have historically lost excess nutrients and contributed to degradation of downstream water quality (NASS, 2020; USEPA, 2017). Given the extensive availability of data, which allows detailed statistical analysis across sites with different climatic, soil, and growing conditions, this study evaluated $\mathrm{N}$ management in corn production in the Midwestern U.S. to provide additional insight into this critical issue.

By performing a comprehensive review on current methods for estimating $\mathrm{N}$ needs for corn, Morris et al. (2018) found that current strategies to generate $\mathrm{N}$ fertilizer rate recommendations need to be improved for both environmental and economic reasons. Shepard (2005) reported that farmers who implemented nutrient management plans in Wisconsin applied $\mathrm{N}$ fertilizer at lower rates compared to farmers without plans, although efforts were still needed to ensure the ongoing successful implementation of nutrient management plans. While the core idea of $\mathrm{N}$ management according to the 4Rs seems simple and straightforward, it is challenging to implement site-specific practices that meet crop needs while reducing nitrate- $\mathrm{N}\left(\mathrm{NO}_{3}-\mathrm{N}\right)$ losses to the environment. The many challenges involved in this decision-making process are detailed below.

First, estimating crop $\mathrm{N}$ needs is crucial but difficult due to variable weather (e.g., rainfall and temperature) and $\mathrm{N}$ cycle interactions. Sources of $\mathrm{N}$ include, but are not limited to, commercial fertilizers, animal manures, legume fixation, atmospheric deposition, green manures, mineralization of plant or crop residues, compost, organic by-products, municipal and industrial biosolids, wastewater, and other organic materials. Loss pathways for $\mathrm{N}$ may include artificial drainage, leaching through soils with high permeability, denitrification in poorly drained soils, immobilization by soil organic matter, plant uptake, surface runoff, and volatilization. However, plant-available $\mathrm{N}$ and loss pathways are not always well quantified. In addition, drainage system management and design strategies can influence the magnitude of $\mathrm{N}$ losses, as well as accelerate the response of export pathways to precipitation events (Strock et al., 2011). Factors such as depth to drains, spacing of drain tiles, and the implementation of controlled drainage can all impact $\mathrm{N}$ losses and plantavailable $\mathrm{N}$ in soils.

Second, fertilization is inherently a complex decisionmaking process, which can be difficult to evaluate effectively and comprehensively. For example, Christianson and Harmel (2015) summarized peer-reviewed literature and reported eleven different fertilizer types (excluding unspecific N) with no predominant source. Coupled with different application methods and timing, farmers have many combinations of fertilization alternatives, which makes management decisions and research evaluation of effectiveness difficult.

Third, the biogeochemical processes involved in $\mathrm{NO}_{3}-\mathrm{N}$ export are complex and exhibit high spatiotemporal heterogeneity, which often leads to conflicting and controversial results. For example, the relative position of agricultural fields, slope, soil organic matter content, heterogeneous soil horizons, and fertilizer type all impact $\mathrm{NO}_{3}-\mathrm{N}$ export. For the impacts of different fertilizer sources on crop yields and water quality, Lawlor et al. (2011) found that application of liquid swine manure resulted in higher crop yields, as well as higher $\mathrm{NO}_{3}-\mathrm{N}$ losses in subsurface drainage water, compared to aqua-ammonia N. However, Chinkuyu et al. (2002) found that application of laying hen manure resulted in significantly higher crop yields but significantly lower $\mathrm{NO}_{3}-\mathrm{N}$ loss in subsurface drainage water compared to urea ammonium nitrate (UAN) at the same rate $\left(168 \mathrm{~kg} \mathrm{~N} \mathrm{ha}^{-1}\right)$. Aronsson et al. (2007) also demonstrated that organic fertilizer had less $\mathrm{NO}_{3}-\mathrm{N}$ loss than inorganic fertilizers but produced lower crop yields in general. They concluded that although organic farms tend to have lower nutrient losses per unit of field area, the effect expressed per unit product is greater given the lower land use efficiency of organic farming as a result of lower yields. These lower yields could be a result of the fertilizer source, nutrient uptake efficiency, or changes made to planting and management schedules to accommodate other organic farming objectives.

Lastly, detailed and effective cost analysis is essential for policy-makers to implement promotion measures (e.g., tax credits) and encourage widespread adoption. It is critical that farmers have science-based information to properly evaluate the benefits and risks of nutrient management, including economic benefits and risks (Sela et al., 2018).

To address the challenges related to system complexity, spatiotemporal heterogeneity, and conflicting results, we conducted a systematic review and synthesis based on existing peer-reviewed publications on $\mathrm{N}$ management in corn production systems with subsurface drainage. Synthetic analysis enables us to work on larger and more complex datasets collected from various field studies with various fertilizer rates, sources, methods, and timing (Christianson and Harmel, 2015; Daryanto et al., 2017; Ni et al., 2020) so that nutrient management (the 4Rs) can be evaluated for a range of site-specific conditions. Such evaluations cannot be done in individual studies with limited experimental designs and resources. On the other hand, as the data from intensive studies involve site-specific uncertainties, we also constrained this research to the Midwest U.S.

Our specific objectives were: (1) to synthesize available information on $\mathrm{N}$ fertilizer rate, source, application method and timing, along with related drainage water quality data, to obtain a systematic understanding of how nutrient management affects $\mathrm{N}$ in drainage; and (2) to perform a cost analysis to obtain general insights on performance-based costs 
associated with ACPs. It is hoped that this review will help: (1) to improve nutrient management plans; (2) to inform the selection of ACPs for water quality improvement; (3) to develop recommendations for cost-effective ACPs to be considered for prioritization when funding agencies are developing their programs; and (4) to improve the scientific basis of USDA-NRCS conservation practice standards and document nutrient reduction efforts.

\section{Performance Effectiveness STUDY AREA}

Excessive $\mathrm{N}$ loadings from corn and soybean fields in the Midwest U.S. have been directly linked to occurrences of seasonal hypoxia in the northern Gulf of Mexico (USEPA, 2017). Additionally, due to the prevalence of poorly drained soils under natural conditions and relatively flat topography in the Midwest U.S., artificial drainage systems have been extensively installed in agricultural landscapes (Sugg, 2007). The current strategy of the Hypoxia Task Force, a collaborative effort of federal and state agencies and tribes, is to reduce $\mathrm{N}$ losses through state-level nutrient reduction strategies (e.g., IEPA, 2015; ISU, 2017), which recommend massive adoption of conservation-driven nutrient management practices for nutrient loss reduction (USEPA, 2017). Because the Midwest U.S. is a crucial area for the implementation of optimal nutrient management strategies, we focused our synthesis on Illinois, Indiana, Iowa, Kansas, Michigan, Minnesota, Missouri, Nebraska, North Dakota, Ohio, South Dakota, and Wisconsin. These states encompass approximately 194.4 million hectares of land, with average annual temperatures ranging from less than $3.3^{\circ} \mathrm{C}$ to more than $15.6^{\circ} \mathrm{C}$ and average annual precipitation ranging from about 508 to $1194 \mathrm{~mm}$ (Great Lakes Integrated Sciences and Assessments, http://glisa.umich.edu/media/files/NCA/MTIT_ Historical.pdf).

\section{LITERATURE SEARCH AND SCREENING Literature Sources}

We compiled peer-reviewed research articles from different sources and then selected preliminary research of interest based on primary selection criteria, as listed in table A1 in Appendix A. Subsequently, the corresponding citations were imported into Endnote by manually retrieving in refhive.com, Web of Science and Google Scholar. A citation was abandoned if it could not be retrieved from any of the three sources (mainly due to early publication date or publication in conference proceedings). By screening all data sources listed in table A1 (e.g., MANAGE, the AgBMP database, and STEPL), we were able to extract a total of 625 publications. After using the Find Duplicates function in Endnote, we removed 78 duplicated records and thus compiled 547 citations for further synthesis study.

\section{Search Criteria}

Among all the synthesized publications (547 in total), we reviewed the abstracts and selected publications that met the following criteria (modified from Christianson and Harmel, 2015):
- Study area fell within 12 states of the Midwest U.S. (fig. 1).

- Published between 1980 and 2019.

- Peer-reviewed publications, excluding government reports, extension publications, brief factsheets, etc.

- Data from field studies under natural conditions, excluding numerical modeling studies, lysimeters, simulated rainfall, soil columns, and lab incubations.

- Subsurface drainage systems were installed.

- Corn was planted either as continuous corn or in rotation.

- Fertilizer information was reported.

- Nitrate-N export data (either mass loads or concentrations) were reported at the annual scale, either full year or growing seasons.

After applying these criteria, we narrowed our literature pool down to 43 peer-reviewed publications in the Midwest U.S. (fig. 1). From these 43 studies (24 distinct study sites in six Midwestern states), we synthesized 557 site-years of data. A full bibliography is listed in the Supplemental Material (available at https://doi.org/10.13031/13678018.v1).

\section{Literature Data Compilation AND Processing Data Extraction}

Our data extraction was conducted based on the structure of the latest version of the Measured Annual Nutrient loads from Agricultural Environments (MANAGE) database (V5, updated on May 30, 2018) (https://data.nal.usda.gov/dataset/measured-annual-nutrient-loads-agricultural-environments-manage-database) (Harmel et al., 2008, 2016). Data of interest included site characteristics (e.g., spatial location, drainage system setting, land use, etc.), fertilizer information (rate, source, application method and timing), crop yield, annual precipitation, subsurface drainage volume, and dissolved $\mathrm{N}$ (mostly $\mathrm{NO}_{3}-\mathrm{N}$ ) in drainage. For those citations with records in the MANAGE database, we maintained the original records but went through quality assurance and quality control (QA/QC) afterwards. For those studies not included in the MANAGE database, we manually added the data to the database following the same format. Most of the data were available as tables in the research articles cited or in the main content. We also extracted the results from graphs using online data extraction tools as needed.

\section{Drainage $\mathrm{NO}_{3}-\mathrm{N}$ Loads and Flow-Weighted Concentrations as Response Variables}

Drainage $\mathrm{N}$ loads in the database were mainly represented as $\mathrm{NO}_{3}-\mathrm{N}(94.1 \%$, or 524 out of 557 site-years), while some of the site-years reported $\mathrm{NO}_{3}+$ nitrite $\mathrm{N}\left(\mathrm{NO}_{2}-\mathrm{N}\right)(5.9 \%$, or 33 out of 557). To simplify the data analysis, we did not distinguish between these two dissolved $\mathrm{N}$ species.

In addition to annual $\mathrm{NO}_{3}-\mathrm{N}$ loads $\left(\mathrm{kg} \mathrm{N} \mathrm{ha}^{-1}\right.$ year $\left.{ }^{-1}\right)$ commonly used in previous synthesis studies (Harmel et al., 2016; Christianson and Harmel, 2015), we included flowweighted $\mathrm{NO}_{3}-\mathrm{N}$ concentrations $\left(\left[\mathrm{NO}_{3}-\mathrm{N}\right]\right)$ estimated using equation 1 :

$$
C_{\text {weighted }}=\frac{\text { Load }_{i}}{\text { Discharge }_{i}}
$$




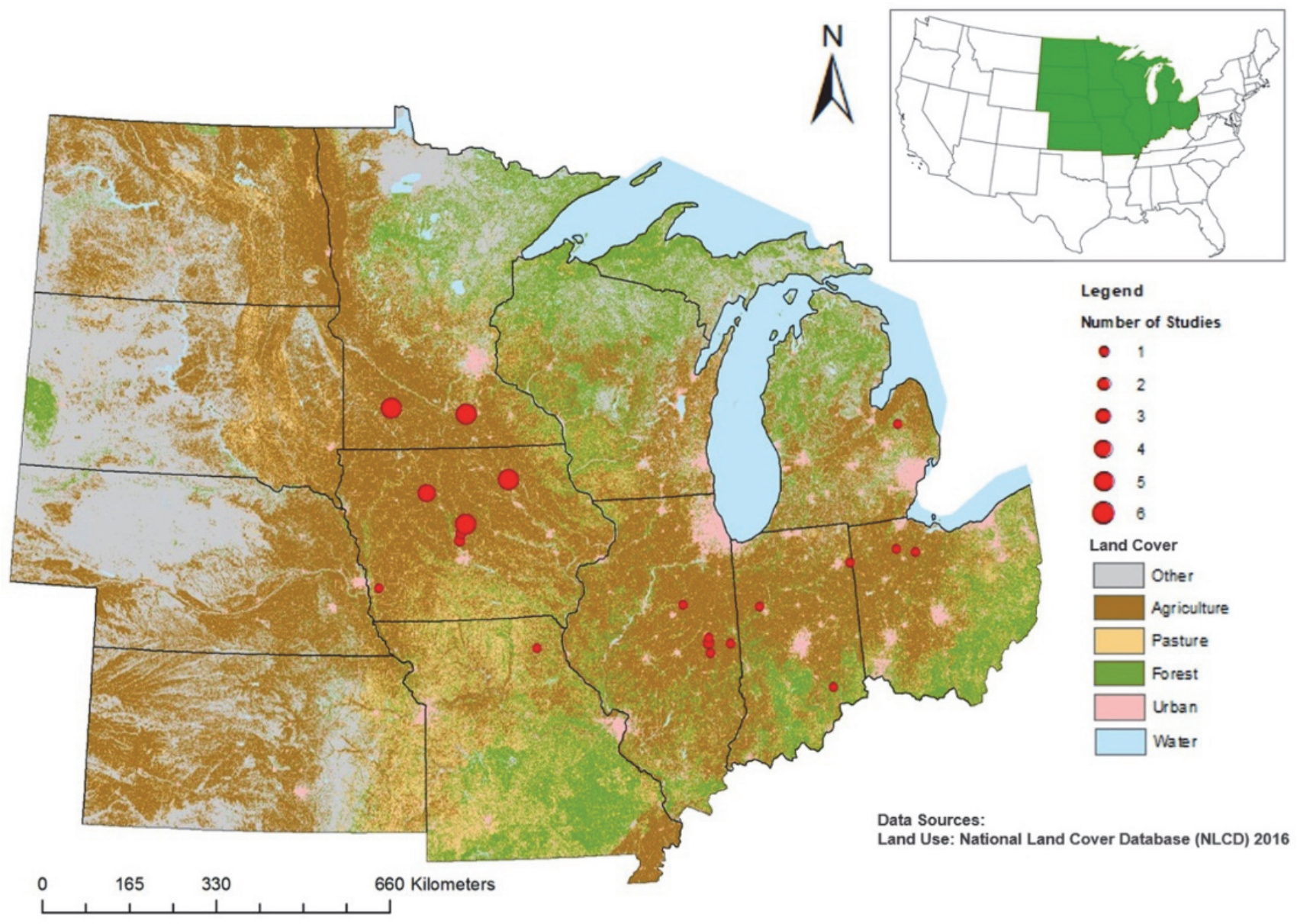

Figure 1. Study area and locations of the fields synthesize in this study.

where $C_{\text {weighted }}$ is the estimated flow-weighted $\left[\mathrm{NO}_{3}-\mathrm{N}\right](\mathrm{mg}$ $\mathrm{N} \mathrm{L}^{-1}$ ), Load $_{i}$ is the reported annual $\mathrm{NO}_{3}-\mathrm{N}$ load at the $i$ th site-year $\left(\mathrm{kg} \mathrm{N} \mathrm{ha}^{-1}\right)$, and Discharge $i$ is the reported annual subsurface discharge at the $i$ th site-year as depth $(\mathrm{mm})$.

Flow-weighted $\left[\mathrm{NO}_{3}-\mathrm{N}\right]$ was used as the main response variable to remove the impacts of different drainage discharge volumes caused by variability in precipitation patterns at both spatial and temporal scales. This issue was also raised by Christianson and Harmel (2015), who separated the site-years within their dataset into two categories, i.e., wet $(>850 \mathrm{~mm})$ and dry $(<820 \mathrm{~mm})$, using the approximate mean and median values for precipitation data. In addition, we verified the estimated flow-weighted concentrations (eq. 1) using reported concentrations and found that they were highly correlated (Appendix B). To keep the results consistent among studies, we employed the same method to estimate flow-weighted $\left[\mathrm{NO}_{3}-\mathrm{N}\right]$ in drainage for all studies.

\section{Fertilizer Rates, Sources, and Application Methods}

In the synthesized dataset, $\mathrm{N}$ fertilizer rates, sources, and methods were reclassified to facilitate analysis. Site-years with different fertilizer rates were separated into four categories: low, moderate, high, and very high. These categories simply represent the fertilizer rate quartiles from the dataset for the purposes of statistical analysis and do not represent fertilizer rate recommendations. Within the fertilizer rate groups, we did not distinguish between available $\mathrm{N}$ in synthetic (inorganic) and organic fertilizers. Reported fertilizer sources were summarized into three major groups: inorganic, organic, and other (table 1). We did not categorize site-years based on inorganic fertilizer sources that did not contain N (e.g., triple superphosphate). For fertilizer application methods, we used the same definitions as in the MANAGE database (injected, incorporated, surface applied, and banded).

Table 1. Categories for $\mathbf{N}$ fertilizer rates, sources, and application methods (UAN = urea ammonium nitrate).

\begin{tabular}{lc}
\hline \multicolumn{1}{c}{ Categories } & Descriptions \\
\hline Fertilizer rates & \\
Low & $<134 \mathrm{~kg} \mathrm{~N} \mathrm{ha}^{-1}$ \\
Moderate & 134 to $167 \mathrm{~kg} \mathrm{~N} \mathrm{~h}^{-1}$ \\
High & 167 to $200 \mathrm{~kg} \mathrm{~N} \mathrm{ha}^{-1}$ \\
Very high & $>200 \mathrm{~kg} \mathrm{~N} \mathrm{~h}^{-1}$ \\
\hline Fertilizer sources & \\
Inorganic & Urea, UAN, and other synthetic fertilizers \\
Organic & Liquid manure and manure \\
Other & No specific sources or no fertilizer applied \\
\hline Application methods ${ }^{[a]}$ & - \\
Injected & - \\
Incorporated & - \\
Surface applied & Including broadcast applied \\
Banded & - \\
[a] & \\
Definitions of application methods are the same as in Christianson and \\
Harmel (2015).
\end{tabular}




\section{SPlit APPlication}

In the synthesized dataset, researchers recorded up to two fertilization events during one growing season (following Harmel et al., 2016). If only one fertilization event was reported, the site-year was categorized as a single application; otherwise, the site-year was classified as a split application. There were some exceptions where different fertilizers were applied in two adjacent fields (David et al., 1997) or the second fertilization did not include N (e.g., triple superphosphate in Randall et al., 2000). In such cases, the site-years were categorized as single applications, even though two fertilization events were reported.

\section{Fertilization Timing: SPRING APPLiCATION VERSUS FALL APPLICATION}

In the Midwest U.S., state-level nutrient reduction strategies emphasize transitioning fall-applied $\mathrm{N}$ to the spring as pre-plant or side-dress $\mathrm{N}$ applications to more closely align with the timing of peak $\mathrm{N}$ demand of corn and reduce the potential for N loss (Ribaudo et al., 2011; IEPA, 2015; ISU, 2017). Thus, for the selected 43 peer-reviewed publications, we reviewed and summarized fertilizer application timing information. We attempted to record fertilizer type (source), application amount (rate), timing (fall vs. spring), crop yield, other ACPs implemented (if any), and drainage $\mathrm{NO}_{3}-\mathrm{N}$ load and concentration.

\section{Statistical Analysis}

All data analyses and visualizations for the database synthesis were completed in R (R Development Core Team, 2011) with third-party packages including dplyr (Wickham et al., 2015) and ggplot2 (Wickham, 2011). Because the dataset was summarized from existing literature with various site characteristics and experimental designs, the dataset among groups (table 1) showed non-normality and stochastic heterogeneity. Therefore, we employed robust analysis of variance (ANOVA) methods with bootstrap and trimmed means using the WRS2 package (Mair and Wilcox, 2019) in $R$. If the differences among groups were found to be significant, post-hoc tests were conducted to identify the specific differences between each pair of group comparisons.

\section{COST-BENEFIT ANALYSIS}

As part of this literature review and synthesis, we evaluated the relative costs associated with the implementation of different $\mathrm{N}$ management strategies in corn cropping systems in the Midwest U.S. Relevant input values for costs, prices, yields, and other parameters were gathered from the USDA National Agricultural Statistics Service (NASS), the Iowa State University Cooperative Extension Service, and other Midwest U.S. university extension service publications. More details on inputs and calculations can be found in Appendix A.

\section{QUALITY ASSURANCE AND QUALITY CONTROL}

Thorough QA/QC procedures were undertaken throughout this synthesis, from literature screening to data processing to statistical analysis. First, during literature screening, the retrieval and removal of publications were reviewed again after going through each database. The review process included double-checking the quantity of processed literature and re-visiting the abstracts and full text of the articles used. Second, several QA/QC measures were undertaken for data compilation and processing. The most important response variable in the dataset was found to be the estimated flow-weighted $\left[\mathrm{NO}_{3}-\mathrm{N}\right]$ for each site-year. The extreme values of $\left[\mathrm{NO}_{3}-\mathrm{N}\right]$, either too great $\left(>30 \mathrm{mg} \mathrm{N} \mathrm{L}^{-1}\right)$ or too little $\left(<5 \mathrm{mg} \mathrm{N} \mathrm{L}^{-1}\right)$, were verified by referencing the original publication. Although most of the records did not change, 18 site-years were removed due to equipment malfunction or extremely dry conditions reported by the authors, and 31 site-years employed the reported concentrations instead of estimated values. Furthermore, the overall distributions of crop yields, subsurface discharge, and $\mathrm{NO}_{3}-\mathrm{N}$ loads were plotted and reviewed. Additionally, any missing fertilization information was searched again from other publications by the authors and filled in if we found a match. Lastly, we generated a reproducible output for data analysis, in the form of archived $\mathrm{R}$ code, and the results were double-checked at multiple locations in the script.

\section{WATER QUALITY IMPACTS OF NUTRIENT MANAGEMENT \\ Brief Summary of Compiled Dataset}

In total, we compiled 557 site-years from 43 publications. Synthesized site-years were spread across 24 study sites in six Midwest states (fig. 1). Most of the studies were from Iowa ( $59 \%, 330$ out of 557 site-years) and Minnesota (24\%, 131 out of 557 site-years). While the literature pool was limited to studies that were published from 1980 to 2019, data contained in these studies were collected from 1969 to 2010, with about half of the site-years of data collected in the 1990s (50\%, 280 out of 557 site-years).

Among all the site-years, the distributions of $\mathrm{N}$ fertilizer rates, corn yields, drainage discharge, and $\mathrm{NO}_{3}-\mathrm{N}$ concentrations and loads (table 2$)$ exhibited non-normality $(\mathrm{p}<0.001)$. In addition, all the tested variables were significantly statistically homogeneous $(\mathrm{p}<0.001)$ among rate groups (defined in table 1), except for $\mathrm{NO}_{3}-\mathrm{N}$ load $(\mathrm{p}=0.18)$. Specifically, the maximum $\mathrm{NO}_{3}-\mathrm{N}$ load and flow-weighted $\left[\mathrm{NO}_{3}-\mathrm{N}\right]$ were $138.7 \mathrm{~kg} \mathrm{~N} \mathrm{ha}^{-1}$ and $70.3 \mathrm{mg} \mathrm{N} \mathrm{L}^{-1}$, with mean values of 29.2 $\mathrm{kg} \mathrm{N}$ ha ${ }^{-1}$ and $14.6 \mathrm{mg} \mathrm{N} \mathrm{L}^{-1}$, respectively. Corn yields in most site-years were less than $10 \mathrm{Mg} \mathrm{ha}^{-1}$ (third quartile < 10.1 $\mathrm{Mg} \mathrm{ha}^{-1}$ ). We recorded statistics on the fertilization information for the first fertilization event (not including the second fertilization) for the 557 synthesized site-years (table 3 ). Urea ammonium nitrate was the most commonly used fertilizer ( $n=189$ site-years), and injected application was the most widely employed method in the first fertilization event.

Table 2. Summary statistics of fertilizer rates, corn yields, discharge, $\mathrm{NO}_{3}-\mathrm{N}$ loads and concentrations for all site-years.

\begin{tabular}{cccccc}
\hline & $\begin{array}{c}\text { Fertilizer } \\
\text { Rate } \\
\text { Statistic }\end{array}$ & $\begin{array}{c}\text { Corn } \\
\text { Yield } \\
\left(\mathrm{kg} \mathrm{ha}^{-1}\right)\end{array}$ & $\begin{array}{c}\text { Discharge } \\
\left(\mathrm{Mg} \mathrm{ha}^{-1}\right)\end{array}$ & $\begin{array}{c}\mathrm{NO}_{3}-\mathrm{N} \\
\text { Load }\end{array}$ & $\begin{array}{c}\left.\mathrm{kg} \mathrm{N} \mathrm{ha}^{-1}\right) \\
\left(\mathrm{kg} \mathrm{O}_{3}-\mathrm{N}\right]\end{array}$ \\
\hline Minimum & 0 & 0.9 & 0 & 0 & 0.9 \\
1st Quartile & 134 & 7.1 & 94.0 & 11.0 & 9.3 \\
Median & 167 & 8.7 & 175.0 & 24.0 & 16.6 \\
Mean & 158 & 8.5 & 209.9 & 29.2 & 14.6 \\
3rd Quartile & 200 & 10.1 & 287.0 & 41.0 & 17.9 \\
Maximum & 326 & 13.9 & 1153.0 & 138.7 & 70.3 \\
\hline
\end{tabular}


Table 3. Number of site-years within each category for primary fertilization events in the dataset (UAN = urea ammonium nitrate).

\begin{tabular}{llc}
\hline Categories & & Site-Years \\
\hline Fertilizer type & UAN & 189 \\
& Anhydrous ammonia & 140 \\
& Liquid manure & 49 \\
& Aqueous ammonia & 38 \\
& Urea & 38 \\
& Other & 103 \\
\hline Fertilizer method & Injected & 297 \\
& Incorporated & 50 \\
& Surface applied & 31 \\
& Banded & 10 \\
& Not specified & 169 \\
\hline Fertilizer timing & Pre-plant & 150 \\
& At planting & 127 \\
& Side/top dress & 89 \\
& Out of season & 112 \\
& Not specified & 79 \\
\hline Split fertilization & Split & 185 \\
& Single & 372 \\
\hline
\end{tabular}

The distribution of fertilization timing was more uniform compared with the other fertilization variables (table 3).

\section{Response of Crop Yields and $\mathrm{NO}_{3}-\mathrm{N}$ Losses to Fertilizer Application Rates}

Both corn yields (fig. 2a) and flow-weighted $\left[\mathrm{NO}_{3}-\mathrm{N}\right]$ (fig. 2b) generally increased in response to increased $\mathrm{N}$ fertilizer rate. For instance, the median value for corn yield was 7.1 $\mathrm{Mg} \mathrm{ha}^{-1}$ for low fertilizer rates $\left(<134 \mathrm{~kg} \mathrm{~N} \mathrm{ha}^{-1}\right)$, while the median value was $9.0 \mathrm{Mg} \mathrm{ha}^{-1}$ for moderate fertilizer rates (134 to $167 \mathrm{~kg} \mathrm{~N} \mathrm{ha}^{-1}$ ); furthermore, the median values were $9.0 \mathrm{Mg} \mathrm{ha}^{-1}$ and $9.6 \mathrm{Mg} \mathrm{ha}^{-1}$ for high (167 to 200 $\left.\mathrm{kg} \mathrm{N} \mathrm{ha}^{-1}\right)$ and very high (>200 $\left.\mathrm{kg} \mathrm{N} \mathrm{ha}^{-1}\right)$ fertilizer rates, respectively. The yield boost was much more significant for lower rate groups (from low to medium) (fig. 2a), and the median yield values were not significantly different between the moderate, high, and very high rate groups (fig. 2a).

This relationship between corn yield and $\mathrm{N}$ fertilizer rate is consistent with other studies which showed that yields increase as fertilizer rate increases, but at some point, increased fertilizer rate does not significantly increase yields (i.e., from the moderate to the high groups) (e.g., Jaynes and Colvin, 2006; Lawlor et al., 2008). The response of flowweighted $\left[\mathrm{NO}_{3}-\mathrm{N}\right]$ (fig. $2 \mathrm{~b}$ ) to fertilizer rate is different from that of crop yield (fig. 2a), as the change in concentration is smaller for low rate groups (i.e., low to medium) but higher for higher rate groups (i.e., high to very high). These findings regarding corn yields and $\mathrm{NO}_{3}-\mathrm{N}$ export were consistent with previous studies (e.g., Chichester and Richardson, 1992; Jaynes and Colvin, 2006; Lawlor et al., 2008; Helmers et al., 2012). In addition, [ $\left.\mathrm{NO}_{3}-\mathrm{N}\right]$ showed much less variation within each rate group and exhibited a stronger positive relationship with application rates compared to $\mathrm{NO}_{3}-\mathrm{N}$ loads (fig. A1 in Appendix A). This strong relationship supported the hypothesis that using flow-weighted concentrations estimated by equation 1 helps to reduce the impacts of variations caused by spatiotemporal variabilities in annual precipitation and soils. Therefore, further analysis will treat flowweighted $\left[\mathrm{NO}_{3}-\mathrm{N}\right]$ as the primary response variable to evaluate the effectiveness of $4 \mathrm{R}$ nutrient management strategies in the context of $\mathrm{N}$ management in corn.

Although optimal $\mathrm{N}$ rate application is considered the most important strategy among the $4 \mathrm{R}$ recommendations (Shepard, 2005; Christianson and Harmel, 2015), the impacts on yields and $\mathrm{NO}_{3}-\mathrm{N}$ losses are not always clear. For an extreme, if we reduce the fertilizer rates from $>200$ to $<134 \mathrm{~kg} \mathrm{~N} \mathrm{ha}^{-1}$, the mean values of flow-weighted $\left[\mathrm{NO}_{3}-\mathrm{N}\right]$ drop considerably from 18.2 to $11.3 \mathrm{mg} \mathrm{N} \mathrm{L}^{-1}$ (fig. 2). However, corn grain yields drop significantly from 9.6 to $8.0 \mathrm{Mg}$ $\mathrm{ha}^{-1}$, and both are much lower than the national average, which was $13.5 \mathrm{Mg} \mathrm{ha}^{-1}$ from 2016 to 2018 (NASS, 2019). Therefore, it is critical to provide farmers with scientific information and to support optimal rate recommendations that balance profitability with environmental impacts in corn production (Jaynes et al., 2001; Lawlor et al., 2008; Christianson et al., 2013; Marshall et al., 2018; Morris et al., 2018).

Many studies have attempted to estimate optimal $\mathrm{N}$ rates, but these rates vary due to site-specific conditions (Mamo et al., 2003; Kladivko et al., 2004). In this study, large a

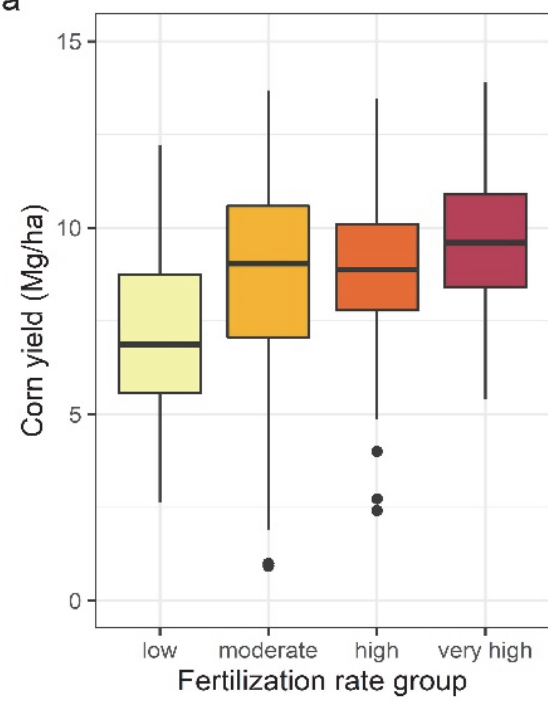

b

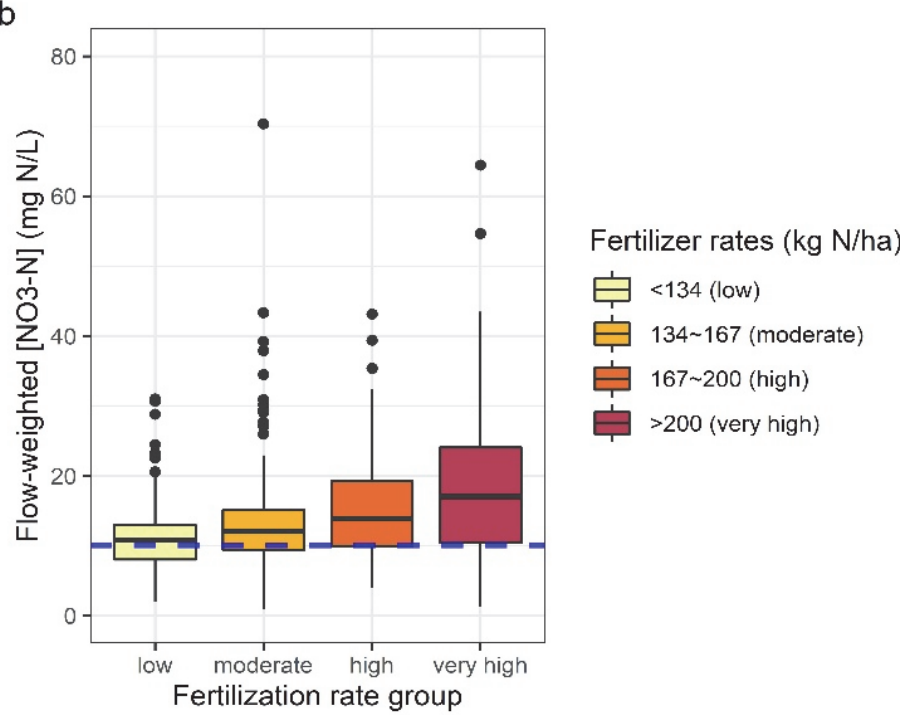

Figure 2. (a) Corn yield and (b) flow-weighted $\left[\mathrm{NO}_{3}-\mathrm{N}\right]$ for different categories of fertilizer rates. The blue dashed line in (b) represents the threshold concentration for $\mathrm{NO}_{3}-\mathrm{N}$ in drinking water recommended by the USEPA $\left(10 \mathrm{mg} \mathrm{N} \mathrm{L}^{-1}\right)$. 
variances in annual $\left[\mathrm{NO}_{3}-\mathrm{N}\right]$ (fig. $2 b$ ) make it difficult to evaluate the effectiveness of optimal $\mathrm{N}$ application on drainage $\mathrm{N}$ losses. Such large variances are likely due to different site characteristics, implementation of other BMPs (Kaspar et al., 2007; Oquist et al., 2007), other N sources (e.g., mineralization in David et al., 1997), and/or potential legacy impacts from previous fertilization (Van Meter et al., 2018).

The majority of site-years $(>70 \%)$ generated higher $\left[\mathrm{NO}_{3}-\mathrm{N}\right]$ levels than the USEPA drinking water standard (10 $\mathrm{mg} \mathrm{N} \mathrm{L}^{-1}$ ), which agrees with previous studies (Jaynes et al., 2001; Kaspar et al., 2007; Lawlor et al., 2008; Nguyen et al., 2013). Similarly, Hertzberger et al. (2019) reported that more than half of the site-years reporting data on $\left[\mathrm{NO}_{3}-\mathrm{N}\right]$ from studies contained in the MANAGE database exceeded the $10 \mathrm{mg} \mathrm{N} \mathrm{L}^{-1}$ standard. These exceedances could potentially be mitigated prior to reaching downstream source waters with in-stream biogeochemical processes, e.g., plant uptake and denitrification (Birgand et al., 2007).

\section{Impacts of Fertilizer Sources on \\ Crop Yields and $\mathrm{NO}_{3}-\mathrm{N}$ Losses}

For those records with a single fertilization event, organic fertilizer consistently produced higher corn yields compared to inorganic fertilizer for all fertilizer rate groups; however, organic fertilizer also produced higher flow-weighted $\left[\mathrm{NO}_{3}-\right.$ $\mathrm{N}]$ for all rate groups except the very high group (fig. 3). Results of two-way ANOVA (table 4) indicated that the interaction among fertilizer rates and sources was not significant $(p=0.161)$. Comparison of fertilizer rate groups (table A2 in Appendix A) showed that organic fertilizers generated significantly higher $\mathrm{NO}_{3}-\mathrm{N}$ export in the low and high fertilizer rate groups $(\mathrm{p}<0.05)$ and insignificant differences for the moderate $(\mathrm{p}=0.15)$ and very high $(\mathrm{p}=0.76)$ groups.

Previously published studies have shown mixed results regarding corn yields and $\mathrm{NO}_{3}-\mathrm{N}$ loss from organic compared to inorganic $\mathrm{N}$ fertilizers. For example, Chinkuyu et al. (2002) and Aronsson et al. (2007) showed lower $\mathrm{NO}_{3}-\mathrm{N}$ losses from organic fertilization, while the present synthesis showed higher $\mathrm{NO}_{3}-\mathrm{N}$ losses except in the very high
Table 4. Robust two-way ANOVA of $\left[\mathrm{NO}_{3}-\mathrm{N}\right]$ among different fertilizer rates, sources, application methods, and split fertilization $(\alpha=0.05)$.

\begin{tabular}{ccc}
\hline Comparison & Source of Variance & $\mathrm{p}$-Value \\
\hline Fertilizer sources $^{[\mathrm{a}]}$ at & Fertilizer rates $(\mathrm{R})$ & 0.004 \\
different rate groups & Fertilizer sources (S) & 0.008 \\
& $\mathrm{R} \times \mathrm{S}$ & 0.161 \\
\hline Application methods $^{[\mathrm{b}]}$ at & $\mathrm{R}$ & 0.386 \\
different rate groups & Application methods (M) & 0.980 \\
& $\mathrm{R} \times \mathrm{M}$ & 0.062 \\
\hline Split fertilization at & $\mathrm{R}$ & 0.386 \\
different rate groups & Split fertilization (SF) & 0.352 \\
& $\mathrm{R} \times \mathrm{SF}$ & $<0.001$ \\
\hline
\end{tabular}

[a] Only inorganic and organic sources were included in the analysis.

[b] Surface applied was not included in the analysis.

fertilizer rate group (fig. 3). Lower corn yield was also reported by Aronsson et al. (2007), but other studies found that organic fertilizer (mostly manure or litter) increased corn yields (e.g., Thoma et al., 2005; Endale et al., 2009; Lawlor et al., 2011). Similarly, Christianson and Harmel (2015) reported a significant corn yield boost in their database analysis $(\mathrm{p}<0.001)$. In accordance with increased corn yields by organic fertilizer, perhaps due to increased plant uptake of $\mathrm{N}$, it is reasonable to hypothesize that organic $\mathrm{N}$ fertilizer may provide benefits in agricultural drainage water quality by reducing the amount of $\mathrm{N}$ that is available for loss. However, our data from 372 site-years did not support this hypothesis (fig. 3). Similarly, Christianson and Harmel (2015) found no significant differences in dissolved $\mathrm{N}$ loads between organic and inorganic sources.

While increased corn yields may imply increased $\mathrm{N}$ uptake or $\mathrm{N}$ use efficiency from the perspective of $\mathrm{N}$ balance, there are many caveats to drawing conclusions regarding the impacts of $\mathrm{N}$ fertilizer sources on water quality $\left(\mathrm{NO}_{3}-\mathrm{N}\right.$ export). First, Christianson and Harmel (2015) indicated that comparison between organic and inorganic fertilizer is difficult because of uncertainty in estimates of plant-available $\mathrm{N}$ in organic sources, legacy impacts of previous manure applications (Bakhsh et al., 2005; Thoma et al., 2005), preferential flow impacts (especially for liquid manures; Ball

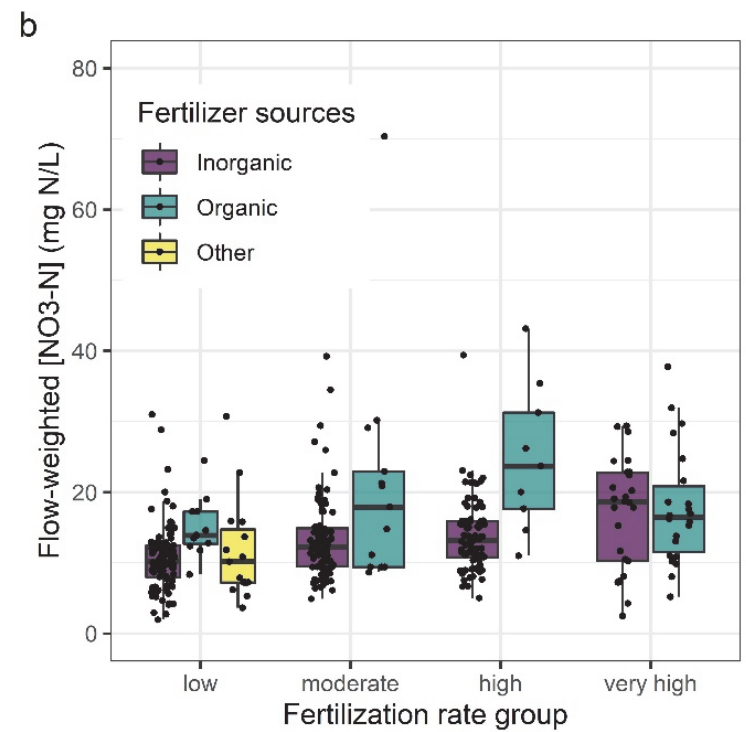

Figure 3. Comparison of (a) crop yield and (b) flow-weighted $\left[\mathrm{NO}_{3}-\mathrm{N}\right]$ for different fertilizer sources at different fertilizer rate groups. Only siteyears with single applications were included in this study (372 site-years in total). 
Coelho et al., 2007; Liu et al., 2020), and complexity of soil $\mathrm{N}$ cycling (David et al., 1997; Endale et al., 2009).

\section{Impacts of Application Methods on Crop Yields and $\mathrm{NO}_{3}-\mathrm{N}$ Losses}

In terms of application method ("right placement" in 4R), injection was the prevailing method (53\%, 297 out of 557 site-years for the first fertilizer application), while incorporation was the second most common method $(9.0 \%, 50$ out of 557 site-years for the first application). If we only consider site-years with single applications, the records for injected and incorporated fertilization decrease to 217 and 48 site-years (out of 287 site-years, excluding those without specific application methods). Because surface application only appeared within the high fertilizer rate group $(n=22$ in fig. 4), this category was removed for the two-way ANOVA.

Results indicated potential differences in corn yield and flow-weighted $\left[\mathrm{NO}_{3}-\mathrm{N}\right]$ between incorporated and injected fertilizer; and in general, injected fertilization produced lower corn yields (except for the moderate fertilizer rate group) as well as lower $\left[\mathrm{NO}_{3}-\mathrm{N}\right]$ (except for the very high fertilizer rate group). Surface application produced the lowest corn yields and lowest $\left[\mathrm{NO}_{3}-\mathrm{N}\right]$ in subsurface drainage for the high fertilizer rate group, although surface application without incorporation is not considered a best practice for nutrient management due to potential yield decline and increased $\mathrm{NO}_{3}-\mathrm{N}$ losses via runoff and volatilization.

Results from two-way ANOVA indicated that the differences among the fertilizer rate groups, application methods, and their interactions were not statistically significant $(\mathrm{p}>$ 0.05 , in table 4). However, we cannot directly conclude that insignificant results mean that the methods did not affect corn yields or $\mathrm{NO}_{3}-\mathrm{N}$ export. Additionally, not all of the practices are considered to be best practices.

\section{Impacts of Split Fertilization on \\ Crop Yields and $\mathrm{NO}_{3}-\mathrm{N}$ Losses}

In the synthesized dataset, researchers reported single applications of $\mathrm{N}$ fertilizer ( $n=372$ site-years) more often than

a

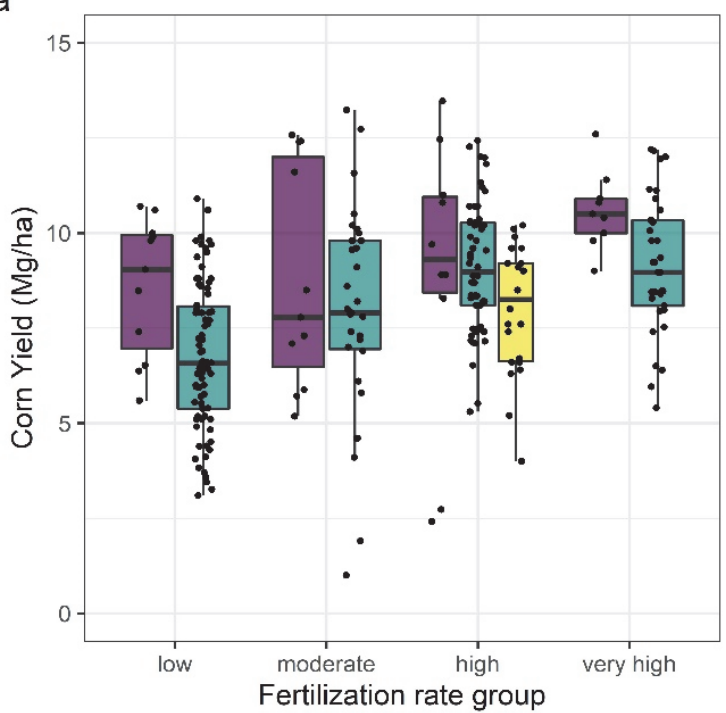

split fertilization ( $n=185$ site-years). Overall, corn yields in single application treatments $\left(\right.$ mean $=8.3 \mathrm{Mg} \mathrm{ha}^{-1}$ ) were lower than those for split application (mean $=9.1 \mathrm{Mg} \mathrm{ha}^{-1}$ ). However, single application treatments generated about the same or higher flow-weighted $\left[\mathrm{NO}_{3}-\mathrm{N}\right]$ than split application, except for the high fertilizer rate group (fig. 5). In addition, split fertilization did not show strong differences among fertilizer rate groups ( $p>0.05$ in table A2). However, results from two-way ANOVA indicated that the interaction between fertilizer application rate and split fertilization was significant $(\mathrm{p}<0.001)$.

Post-hoc comparisons showed that the relationship with flow-weighted $\left[\mathrm{NO}_{3}-\mathrm{N}\right]$ under split fertilization significantly shifted for above and below the median fertilizer rate $\left(167 \mathrm{~kg} \mathrm{~N} \mathrm{ha}^{-1}\right)$. More specifically, split fertilization generated less $\mathrm{NO}_{3}-\mathrm{N}$ export at lower fertilizer rates $(<167 \mathrm{~kg} \mathrm{~N}$ $\mathrm{ha}^{-1}$ ), as shown by Bjorneberg et al. (1998), and comparable $\mathrm{NO}_{3}-\mathrm{N}$ losses at higher fertilizer rates $\left(\geq 167 \mathrm{~kg} \mathrm{~N} \mathrm{ha}^{-1}\right)$ compared to single fertilization (table A3 in Appendix A).

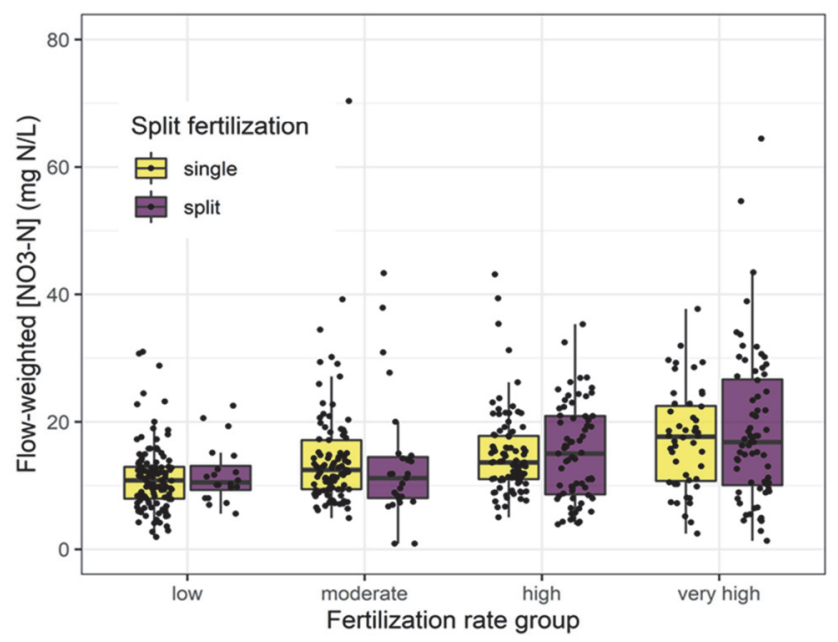

Figure 5. Comparison of flow-weighted $\left[\mathrm{NO}_{3}-\mathrm{N}\right]$ for split fertilization at different fertilizer rate groups. Outliers are not shown in this figure. Data from 577 site-years are reported.

b

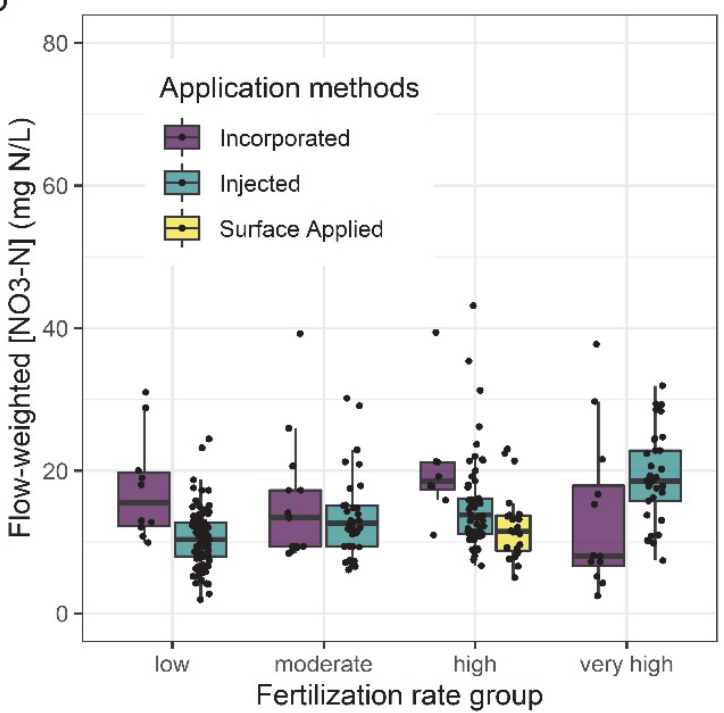

Figure 4. Comparison of (a) crop yield and (b) flow-weighted $\left[\mathrm{NO}_{3}-\mathrm{N}\right]$ for different fertilizer application methods at different fertilizer rate groups. Only site-years with single applications were included in this figure $(n=287)$. 
Because the differences in concentration between split and single applications were generally small, potential water quality benefits could be masked by many other factors, e.g., fertilizer rate or timing, and thus not be recognized (Kanwar et al., 1988; Jaynes and Colvin, 2006; Jaynes, 2013).

\section{Impacts of Fertilization Timing on Crop Yields and $\mathrm{NO}_{3}-\mathrm{N}$ Losses}

With regard to $\mathrm{N}$ application timing, results were mixed. Switching from fall application to a majority spring application resulted in changes from $-67 \%$ to $52 \%$ in subsurface $\mathrm{NO}_{3}-\mathrm{N}$ loads (Rejesus and Hornbaker, 1999; Randall and Mulla, 2001; Randall et al., 2003a, 2003b; Dinnes, 2004; Randall and Vetsch, 2005). In a five-year study, Lawlor et al. (2011) found that fall application resulted in lower average nitrate-N losses compared to spring application, but the differences were not significant. For slightly dry to normal precipitation conditions, corn yields were not significantly different $(p=0.05)$ between fall and spring application; however, corn yields were significantly greater $(p=0.05)$ for spring and fall manure $\left(218 \mathrm{~kg} \mathrm{~N} \mathrm{ha}^{-1}\right)$ than for non-manure treatments. Similarly, Ruffatti et al. (2019) found that falldominated $\mathrm{N}$ application resulted in $25 \%$ lower $\mathrm{NO}_{3}-\mathrm{N}$ losses $\left(39.0 \mathrm{~kg} \mathrm{~N} \mathrm{ha}^{-1}\right)$ compared to spring-dominated $\mathrm{N}$ application $\left(48.9 \mathrm{~kg} \mathrm{~N} \mathrm{ha}^{-1}\right)$, but the three-year average annual concentrations were $11 \%$ higher for fall application (the differences were not significant). However, inclusion of cover crops (cereal rye-radish blend) with spring fertilization resulted in $39 \%$ and $47 \%$ reductions in $\mathrm{NO}_{3}-\mathrm{N}$ concentrations and loads, respectively; and inclusion of cover crops in fall fertilization treatment resulted in $38 \%$ and $40 \%$ reductions in $\mathrm{NO}_{3}-\mathrm{N}$ concentrations and loads, respectively. Although corn yields were not significantly different $(p=0.05)$ between the fall and spring applications, inclusion of cover crops reduced corn yields significantly.

Overall, for $\mathrm{NO}_{3}-\mathrm{N}$ concentrations and loads, the differences between fall and spring fertilizer $\mathrm{N}$ applications were inconsistent. Other factors, such as seasonal precipitation and its spatiotemporal distribution, drainage volume, crop uptake, fertilizer $\mathrm{N}$ application rate and type, ACPs (such as cereal rye-radish cover crop in Ruffatti et al., 2019), and organic matter mineralization, had a higher impact on $\mathrm{NO}_{3}-\mathrm{N}$ concentrations and loads than application timing. In addition, corn yields were generally not significantly different between fall and spring fertilizer applications.

\section{COST-Benefit ANALYSIS FOR NutRIENT MANAGEMENT}

The nutrient management strategies included in this cost analysis were rate, source, and single/split application. The four application rate groups used for the synthesis of crop yield and water quality data (table 1) were again used, where the rate groups were represented by the means within the group ranges (table 5). For $\mathrm{N}$ sources, we included price data for four different inorganic $\mathrm{N}$ fertilizer types: UAN (28\%), urea ( $44 \%$ to $46 \%$ ), anhydrous ammonia, and aqueous ammonia (table A4 in Appendix A). As there existed less data regarding the prices and efficiencies of manure and compost sources, these sources were not included in the cost analysis. Furthermore, calculations were performed for two scenarios: single application and split application, where the split application strategy involved two $\mathrm{N}$ applications that totaled the given rate category (table 5). A per hectare cost was developed for a hypothetical field located in Iowa under either continuous monoculture corn (Zea mays [L.]) or a corn-soybean (Glycine $\max$ [L.]) rotation with conservation tillage practices (tandem disk tilling once per season). Total present costs were subtracted from estimated gross revenues for each fertilizer source, rate, and single/split application scenario over two seasons and then averaged.

In the cost analysis, we attempted to capture changes in corn grain yields corresponding with $\mathrm{N}$ fertilizer application rate, based on the synthesized data (table A5 in Appendix A) and data adapted from Sawyer and Barker (2017) and the most recent USDA-NASS national survey averages (table A5). The average yield within each rate group was used for continuous corn and corn after soybean. The USDANASS national average yield (2016-2018) was included as a baseline with some basic assumptions: farmers were using the N rate recommended by Iowa State University's corn N rate calculator (in the moderate rate group) to maximize returns in a corn-soybean system (ISU, 2019). In addition, the corresponding corn grain yield was estimated for continuous corn and corn after soybean based on the response curve from Sawyer and Barker (2017) for each rate group and then adjusted so that the recommended fertilizer rate range (ISU, 2019) corresponded with the national average corn grain yield. Fertilizer rate groups were applied only to corn in the rotation scenario, and we did not adjust soybean yield for varying $\mathrm{N}$ fertilizer application rates to corn in the rotation.

For simplicity, we did not account for any tax benefit programs or government subsidies, as dollar values can vary widely based on the program and field eligibility. Additionally, we did not account for projected inflation or attempt to quantify the other impacts associated nutrient management strategies, such as nitrous oxide emissions or the value of ecological services and environmental impacts on downstream water resources. As in any cost analysis, results depend on assumptions made regarding prices, cost inputs, and the relationship between $\mathrm{N}$ fertilizer application rate and corn grain yield. The rest of the cost inputs used are summarized in table A6 in Appendix A.

The results of this analysis showed that all annual net revenues were negative for the synthesized yield data, and, overall, corn-soybean was more profitable than continuous corn (table 5). As fertilizer rate increased, a greater net revenue was achieved for both cropping systems due to increased corn grain yields, despite higher fertilizer costs (table 5). However, this evident trend of increasing net revenue with increasing application rate was not linear. For example, the net revenue increased by $\$ 22 \mathrm{ha}^{-1}$ year $^{-1}$ from the moderate to high fertilizer rate group, while the net revenue increased by $\$ 78 \mathrm{ha}^{-1}$ year $^{-1}$ from the low to moderate fertilizer rate group, for a single application of anhydrous ammonia in continuous corn (table 5). However, the mean drainage flowweighted $\left[\mathrm{NO}_{3}-\mathrm{N}\right]$ increased by $1.5 \mathrm{mg} \mathrm{N} \mathrm{L}^{-1}$ (moderate to high fertilizer rate group) and $2.8 \mathrm{mg} \mathrm{N} \mathrm{L}^{-1}$ (low to moderate 
Table 5. Results of cost analysis for different nutrient management scenarios based on yield data from the synthesized literature as well as adjusted national average yield data (NASS, 2019), mean flow-weighted $\mathrm{NO}_{3}-\mathrm{N}$ concentrations, and loads in subsurface drainage flow associated with each fertilizer rate group (from table 1). For each rate group, the mean within that group was used to calculate net revenue.

\begin{tabular}{|c|c|c|c|c|c|c|c|c|c|c|c|c|}
\hline \multirow{3}{*}{\multicolumn{2}{|c|}{$\begin{array}{c}\text { Cropping } \\
\text { System and } \\
\text { Fertilizer Type }\end{array}$}} & \multirow{3}{*}{$\begin{array}{l}\text { Fertilizer } \\
\text { Rate } \\
\text { Group }\end{array}$} & \multirow{3}{*}{$\begin{array}{c}\text { Fertilizer } \\
\text { Rate }^{[\mathrm{a}]} \\
\left(\mathrm{kg} \mathrm{ha}^{-1}\right)\end{array}$} & \multicolumn{4}{|c|}{$\begin{array}{c}\text { Annual Net Revenue } \\
\left(\$ \text { ha }^{-1} \text { year }^{-1}\right)\end{array}$} & \multirow{3}{*}{$\begin{array}{c}\text { Mean } \\
{\left[\mathrm{NO}_{3}-\mathrm{N}\right] \text { in }} \\
\text { Subsurface } \\
\text { Discharge } \\
\left(\mathrm{mg} \mathrm{N} \mathrm{L}^{-1}\right)\end{array}$} & \multirow{3}{*}{$\begin{array}{l}\text { Annual Net } \\
\text { Revenue } \\
\text { Reduction } \\
\text { from Very } \\
\text { High }^{[b]} \\
(\$)\end{array}$} & \multirow{3}{*}{$\begin{array}{c}\text { Mean } \\
\mathrm{NO}_{3}-\mathrm{N} \\
\text { Load from } \\
\text { Subsurface } \\
\text { Discharge } \\
\left(\mathrm{kg} \mathrm{N} \mathrm{ha}^{-1}\right) \\
\end{array}$} & \multirow{3}{*}{$\begin{array}{c}\text { Mean } \\
\mathrm{NO}_{3}-\mathrm{N} \text { Load } \\
\text { Reduction } \\
\text { from Very } \\
\text { High } \\
(\mathrm{kg})\end{array}$} & \multirow{3}{*}{$\begin{array}{c}\text { Cost-Effec- } \\
\text { tiveness } \\
\quad\left(\mathrm{kg}^{-1}\right. \\
\mathrm{NO}_{3}-\mathrm{N} \\
\text { reduction })\end{array}$} \\
\hline & & & & \multicolumn{2}{|c|}{$\begin{array}{c}\text { Synthesized } \\
\text { Yield Data } \\
\end{array}$} & \multicolumn{2}{|c|}{$\begin{array}{c}\text { Adjusted NASS } \\
\text { Yield Data } \\
\end{array}$} & & & & & \\
\hline & & & & Single & Split & Single & Split & & & & & \\
\hline \multicolumn{13}{|c|}{ Continuous corn } \\
\hline \multirow{4}{*}{\multicolumn{2}{|c|}{ UAN, $28 \%$}} & Low & 83.64 & -793.7 & -821.75 & -481.37 & -509.41 & 12.0 & - & 23.5 & - & - \\
\hline & & Moderate & 146.3 & -687.2 & -715.27 & -353.15 & -381.20 & 15.3 & 44 & 25.5 & 12.5 & 3.5 \\
\hline & & High & 190.1 & -684.21 & -712.25 & -312.66 & -340.71 & 14.6 & 41 & 28.9 & 9.1 & 4.5 \\
\hline & & Very high & 239.9 & -643.25 & -671.30 & -339.41 & -367.46 & 20.3 & - & 38.0 & - & - \\
\hline \multirow{4}{*}{\multicolumn{2}{|c|}{$\begin{array}{l}\text { Anhydrous } \\
\text { ammonia }\end{array}$}} & Low & 83.64 & -756.83 & -784.88 & -444.49 & -472.54 & 12.0 & - & 23.5 & - & - \\
\hline & & Moderate & 146.3 & -622.74 & -650.79 & -288.67 & -316.72 & 15.3 & 85 & 25.5 & 12.5 & 6.8 \\
\hline & & High & 190.1 & -600.36 & -628.41 & -228.82 & -256.87 & 14.6 & 63 & 28.9 & 9.1 & 6.9 \\
\hline & & Very high & 239.9 & -537.49 & -565.54 & -233.65 & -261.70 & 20.3 & - & 38.0 & - & - \\
\hline \multirow{4}{*}{\multicolumn{2}{|c|}{$\begin{array}{l}\text { Aqueous } \\
\text { ammonia }\end{array}$}} & Low & 83.64 & -775.27 & -803.31 & -462.93 & -490.98 & 12.0 & - & 23.5 & - & - \\
\hline & & Moderate & 146.3 & -654.98 & -683.03 & -320.91 & -348.96 & 15.3 & 65 & 25.5 & 12.5 & 5.1 \\
\hline & & High & 190.1 & -642.28 & -670.33 & -270.74 & -298.79 & 14.6 & 52 & 28.9 & 9.1 & 5.7 \\
\hline & & Very high & 239.9 & -590.37 & -618.42 & -286.53 & -314.58 & 20.3 & - & 38.0 & - & - \\
\hline \multirow{4}{*}{\multicolumn{2}{|c|}{$\begin{array}{l}\text { Urea, } 44 \% \\
\text { to } 46 \%\end{array}$}} & Low & 83.64 & -788.17 & -802.50 & -475.84 & -490.17 & 12.0 & - & 23.5 & - & - \\
\hline & & Moderate & 146.3 & -677.55 & -691.88 & -343.48 & -357.81 & 15.3 & 50 & 25.5 & 12.5 & 4.0 \\
\hline & & High & 190.1 & -671.63 & -685.96 & -300.09 & -314.42 & 14.6 & 44 & 28.9 & 9.1 & 4.9 \\
\hline & & Very high & 239.9 & -627.39 & -641.72 & -323.55 & -337.88 & 20.3 & - & 38.0 & - & - \\
\hline \multicolumn{13}{|c|}{ Corn-soybean } \\
\hline \multirow{4}{*}{\multicolumn{2}{|c|}{ UAN, $28 \%$}} & Low & 83.64 & -238.20 & -252.22 & 0.57 & -13.45 & 11.3 & - & 31.1 & - & - \\
\hline & & Moderate & 146.3 & -188.66 & -202.69 & 39.70 & 25.68 & 14.2 & 6 & 28.2 & 6.9 & 0.8 \\
\hline & & High & 190.1 & -188.82 & -202.85 & 26.63 & 12.61 & 15.5 & 6 & 28.9 & 6.2 & 0.9 \\
\hline & & Very high & 239.9 & -183.05 & -197.07 & -3.40 & -17.42 & 15.9 & - & 35.1 & - & - \\
\hline & Anhydrous & Low & 83.64 & -219.76 & -233.79 & 19.01 & 4.99 & 11.3 & - & 31.1 & - & - \\
\hline \multirow{3}{*}{\multicolumn{2}{|c|}{ Ammonia }} & Moderate & 146.3 & -156.43 & -170.45 & 71.94 & 57.92 & 14.2 & 26 & 28.2 & 6.9 & 3.8 \\
\hline & & High & 190.1 & -146.90 & -160.93 & 68.56 & 54.53 & 15.5 & 17 & 28.9 & 6.2 & 2.7 \\
\hline & & Very high & 239.9 & -130.17 & -144.19 & 49.49 & 35.46 & 15.9 & - & 35.1 & - & - \\
\hline & Aqueous & Low & 83.64 & -228.98 & -243.01 & 9.79 & -4.23 & 11.3 & - & 31.1 & - & - \\
\hline \multirow{3}{*}{\multicolumn{2}{|c|}{ Ammonia }} & Moderate & 146.3 & -172.54 & -186.57 & 55.82 & 41.80 & 14.2 & 16 & 28.2 & 6.9 & 2.3 \\
\hline & & High & 190.1 & -167.86 & -181.89 & 47.59 & 33.57 & 15.5 & 11 & 28.9 & 6.2 & 1.8 \\
\hline & & Very high & 239.9 & -156.61 & -170.63 & 23.04 & 9.02 & 15.9 & - & 35.1 & - & - \\
\hline \multirow{4}{*}{\multicolumn{2}{|c|}{$\begin{array}{l}\text { Urea, } 44 \% \\
\text { to } 46 \%\end{array}$}} & Low & 83.64 & -235.44 & -249.46 & 3.34 & -3.83 & 11.3 & - & 31.1 & - & - \\
\hline & & Moderate & 146.3 & -183.83 & -197.85 & 44.54 & 37.37 & 14.2 & 9 & 28.2 & 6.9 & 1.3 \\
\hline & & High & 190.1 & -182.54 & -196.56 & 32.92 & 25.76 & 15.5 & 7 & 28.9 & 6.2 & 1.2 \\
\hline & & Very high & 239.9 & 175.11 & -189.14 & 4.54 & -2.63 & 15.9 & - & 35.1 & - & - \\
\hline
\end{tabular}

fertilizer rate group), respectively, while mean $\mathrm{NO}_{3}-\mathrm{N}$ load stayed about the same.

Although the highest revenue was achieved with the highest fertilizer rate (e.g., very high fertilizer rate group) regardless of fertilizer cost, the $\mathrm{NO}_{3}-\mathrm{N}$ concentrations and loads in drainage were also the highest for this scenario. In fact, the $\mathrm{NO}_{3}-\mathrm{N}$ loads were much higher for the very high groups than for all other fertilizer rate groups (table 5). For example, from the high to very high fertilizer rate group for continuous corn, revenue increased by $\$ 41$ (UAN, 28\%), while the $\mathrm{NO}_{3}$ $\mathrm{N}$ load increased by $9 \mathrm{~kg} \mathrm{~N} \mathrm{ha}^{-1}$ (table 5). In other words, for every hectare, $\mathrm{NO}_{3}-\mathrm{N}$ loads can be reduced by $9 \mathrm{~kg} \mathrm{~N}$ at a cost of $\$ 41$, or about $\$ 5$ per $\mathrm{kg} \mathrm{N}$ reduction (table 5). Therefore, it is important to balance the economic benefits of nutrient management plans with their environmental impacts and account for financial barriers to implementation of conservation-driven nutrient management plans. The trends in our analysis were similar to the finding reported by Sawyer et al. (2006) that higher $\mathrm{N}$ fertilizer rate can result in higher yield, but the corn $\mathrm{N}$ yield response is a nonlinear relationship; after a certain point, applying more fertilizer does not result in a significant increase in corn grain yields but can significantly increase $\mathrm{NO}_{3}-\mathrm{N}$ losses in subsurface drainage discharge (fig. 2 and table 5).

When we used corn grain yield data adjusted for the NASS average, although all annualized net revenues were negative for continuous corn, they were mostly positive for the corn-soybean rotation (table 5). The low corn yields from the synthesized dataset, which resulted in low net revenues, may be due to site-specific study conditions. Unlike farmers, researchers control certain conditions and devise treatments to test hypotheses, but they are often less concerned about the profitability of the agricultural management systems they are testing. Conversely, farmers will necessarily focus on the profitability of their production systems and will attempt to optimize growing conditions to the extent possible to maximize profits. This difference in approach may explain the discrepancy between the corn yields from the synthesized dataset and the corn yields adjusted for the national average, as well as the resulting net revenues.

Fertilizer source and single/split application also influenced the cost analysis results. The single application scenario resulted in greater net revenues than split application for all fertilizer sources due to the additional application 
costs, even though the total amount of fertilizer applied was the same within rate groups. In terms of source, some types of $\mathrm{N}$ fertilizer were more profitable than others, mainly due to the assumptions made regarding prices by weight and varying $\mathrm{N}$ content. For example, urea at $44 \%$ to $46 \% \mathrm{~N}$ content cost about $\$ 0.67$ per pound of N (ISU, 2019; NASS, 2019) and resulted in the second lowest net revenues behind UAN (assumed 28\% $\mathrm{N}$ and $\$ 0.70$ per pound of $\mathrm{N}$ ).

Integration of the cost analysis with water quality data provided more insights on the trade-offs between environmental impacts and profits. For example, in the calculations using corn grain yields from the literature, the greatest net revenue was achieved with the very high fertilizer rate scenario, but this also produced the highest $\mathrm{NO}_{3}-\mathrm{N}$ concentrations and loads (based on subsurface drainage data from the synthesized literature). In other words, the most economically beneficial scenario was the least environmentally beneficial in terms of water quality improvement. In general, it costs four to seven dollars to reduce one $\mathrm{kg}$ nitrate $\mathrm{N}$ from very high to either the high or moderate fertilizer rate groups for continuous corn, and one to four dollars for corn-soybean rotation (table 5). For the cost analysis calculations using corn grain yields based on national averages, the most costeffective scenarios were the ones with the high fertilizer rate in the continuous corn scenario and the moderate rate in the corn-soybean scenario. However, both situations were not as effective in terms of water quality improvement compared to lower fertilizer application rates.

Reduction in net revenue, or perception thereof, is a substantial barrier to farmer adoption of agricultural conservation practices. Therefore, it is important to account for the relative costs associated with implementing a given nutrient management strategy, or any conservation practice, along with the possible environmental benefits. By presenting statistics on available water quality data with results from our simple cost analysis, we aim to develop a more complete understanding of the risks and benefits associated with $\mathrm{N}$ fertilizer management in corn and inform policies that encourage the adoption of conservation-driven management practices that may otherwise be unprofitable. The methods we used for our cost analysis may be applied to evaluations of implementation costs for other agricultural conservation practices and serve as a useful tool in farm cost benefit comparisons.

\section{SUMMARY AND CONCLUSIONS}

This study systematically evaluated the performance of 4R nutrient management strategies with regard to water quality improvement (reductions in $\mathrm{NO}_{3}-\mathrm{N}$ in drainage) and cost-effectiveness. The water quality results showed that, with higher fertilizer rates, corn yields, $\mathrm{NO}_{3}-\mathrm{N}$ loads, and flow-weighted $\left[\mathrm{NO}_{3}-\mathrm{N}\right]$ increased. Reducing fertilizer rate can effectively mitigate $\mathrm{NO}_{3}-\mathrm{N}$ losses from agricultural fields; however, our cost analysis revealed negative economic returns for corn production. Therefore, measures may need to be taken to address the potential economic losses resulting from the implementation of conservation-driven $4 \mathrm{R}$ nutrient management plans by farmers.
Organic fertilizers (manure or litter) were found to significantly boost corn yields, as well as $\mathrm{NO}_{3}-\mathrm{N}$ losses, compared to inorganic fertilizers at comparable application rates. However, difficulties in precisely quantifying the plant-available $\mathrm{N}$ from organic fertilizers make it difficult to draw definitive conclusions. Fertilizer injection and incorporation showed no significant differences in $\mathrm{NO}_{3}-\mathrm{N}$ drainage, but split fertilization was effective in reducing $\mathrm{NO}_{3}-\mathrm{N}$ export at lower fertilizer rates but not at higher rates. In terms of fertilization timing, results were mixed relative to $\mathrm{NO}_{3}-\mathrm{N}$ losses between fall and spring $\mathrm{N}$ fertilizer applications. The effectiveness of fertilization timing was difficult to quantify because of the impacts of other, more influential factors (e.g., weather conditions, fertilizer rates, and cover crops).

The literature synthesis and cost analysis in this study were conducted based on existing publications and many assumptions, especially regarding the economic returns of different fertilization scenarios. Because a perfect and comprehensive economic analysis is impossible, we focused on quantification of the potential impacts on revenue in corn production if a hypothetical farmer decided to implement different nutrient management practices for $\mathrm{N}$ fertilization. Further advanced analyses of the relative costs case by case are still needed to provide accurate suggestions for policymakers, private farm owners, researchers, and other stakeholders in the formulation of cost-assistance programs to encourage implementation of conservation-driven nutrient management plans.

In conclusion, we present the following findings and suggestions to enhance agricultural water quality improvement by nutrient management of $\mathrm{N}$ in corn production systems:

- Reducing fertilizer rates was the most effective practice in 4R nutrient management.

- Additional evaluation is needed to generate more accurate $\mathrm{N}$ fertilization recommendations that consider both environmental and economic benefits.

- Actions and measures are required for regulatory agencies, researchers, and extension specialists to introduce the pros, address the cons, and thus promote the implementation of 4R nutrient management.

\section{ACKNOWLEDGEMENTS}

This project was supported in part by an appointment to the Research Participation Program at the U.S. Environmental Protection Agency (USEPA) Office of Research and Development (ORD), administered by the Oak Ridge Institute for Science and Education (ORISE) Program, through an interagency agreement between the USEPA and the U.S. Department of Energy. Although this manuscript has been reviewed and approved for publication by the Agency, the views expressed in this manuscript are those of the authors and do not necessarily represent the views or policies of the Agency or ORISE. The authors would like to thank Dr. Brent Johnson, Dr. David Smith from the USEPA, the journal editors, and the anonymous reviewers for their technical review and valuable comments and suggestions, which helped improve the manuscript. 


\section{REFERENCES}

Aronsson, H., Torstensson, G., \& Bergström, L. (2007). Leaching and crop uptake of $\mathrm{N}, \mathrm{P}$, and $\mathrm{K}$ from organic and conventional cropping systems on a clay soil. Soil Use Mgmt., 23(1), 71-81. https://doi.org/10.1111/j.1475-2743.2006.00067.x

Bakhsh, A., Kanwar, R. S., \& Karlen, D. L. (2005). Effects of liquid swine manure applications on $\mathrm{NO}_{3}-\mathrm{N}$ leaching losses to subsurface drainage water from loamy soils in Iowa. Agric. Ecosyst. Environ., 109(1-2), 118-128. https://doi.org/10.1016/j.agee.2005.01.018

Bakhsh, A., Kanwar, R. S., Bailey, T. B., Cambardella, C. A., Karlen, D. L., \& Colvin, T. S. (2002). Cropping system effects on $\mathrm{NO}_{3}-\mathrm{N}$ loss with subsurface drainage water. Trans. ASAE, 45(6). https://doi.org/10.13031/2013.11430

Ball Coelho, B. R., Roy, R. C., Topp, E., \& Lapen, D. R. (2007). Tile water quality following liquid swine manure application into standing corn. J. Environ. Qual., 36(2), 580-587. https://doi.org/10.2134/jeq2006.0306

Birgand, F., Skaggs, R. W., Chescheir, G. M., \& Gilliam, J. W. (2007). Nitrogen removal in streams of agricultural catchments: A literature review. Crit. Rev. Environ. Sci. Tech., 37(5), 381487. https://doi.org/10.1080/10643380600966426

Bjorneberg, D. L., Karlen, D. L., Kanwar, R. S., \& Cambardella, C. A. (1998). Alternative $\mathrm{N}$ fertilizer management strategies effects on subsurface drain effluent and N uptake. Appl. Eng. Agric., 14(5), 469-473. https://doi.org/10.13031/2013.19416

Chichester, F. W., \& Richardson, C. W. (1992). Sediment and nutrient loss from clay soils as affected by tillage. J. Environ. Qual., 21(4), 587-590.

https://doi.org/10.2134/jeq1992.00472425002100040010x

Chinkuyu, A. J., Kanwar, R. S., Lorimor, J. C., Xin, H., \& Bailey, T. B. (2002). Effects of laying hen manure application rate on water water quality. Trans. ASABE, 45(2), 299-308. https://doi.org/10.13031/2013.8524

Christianson, L. E., \& Harmel, R. D. (2015). 4R water quality impacts: An assessment and synthesis of forty years of drainage nitrogen losses. J. Environ. Qual., 44(6), 1852-60. https://doi.org/10.2134/jeq2015.03.0170

Christianson, L., Tyndall, J., \& Helmers, M. (2013). Financial comparison of seven nitrate reduction strategies for Midwestern agricultural drainage. Water Resour. Econ., 2-3, 30-56. https://doi.org/10.1016/j.wre.2013.09.001

Daryanto, S., Wang, L., \& Jacinthe, P. A. (2017). Meta-analysis of phosphorus loss from no-till soils. J. Environ. Qual., 46(5), 1028-1037. https://doi.org/10.2134/jeq2017.03.0121

David, M. B., Gentry, L. E., Kovacic, D. A., \& Smith, K. M. (1997). Nitrogen balance in and export from an agricultural watershed. J. Environ. Qual., 26(4), 1038-1048. https://doi.org/10.2134/jeq1997.00472425002600040015x

Delgado, J. A., Vandenberg, B., Kaplan, N., Neer, D., Wilson, G., D'Adamo, R., ... Derner, J. D. (2018). Agricultural Collaborative Research Outcomes System (AgCROS): A network of networks connecting food security, the environment, and human health. $J$. Soil Water Cons., 73(6), 158A-164A. https://doi.org/10.2489/jswc.73.6.158A

Dinnes, D. L. (2004). Assessments of practices to reduce nitrogen and phosphorus nonpoint source pollution of Iowa's surface waters. Ames, IA: USDA-ARS National Soil Tilth Laboratory.

Endale, D. M., Schomberg, H. H., Jenkins, M. B., Franklin, D. H., \& Fisher, D. S. (2009). Management implications of conservation tillage and poultry litter use for Southern Piedmont USA cropping systems. Nutr. Cycling Agroecosyst., 88(2), 299313. https://doi.org/10.1007/s10705-009-9318-z

Fawecett, R., \& Smith, T. (2009). A review of BMPs for managing crop nutrients and conservation tillage to improve water quality. West Lafayette, IN: Conservation Technology Information
Center. Retrieved from

http://past.ctic.org/media/pdf/A\%20Review\%20of\%20BMPs\%2 0For\%20Managing\%20Crop\%20Nutrients.pdf

Harmel, D. R., Christianson, L. E., McBroom, M. W., Smith, D. R., $\&$ Higgs, K. D. (2016). Expansion of the MANAGE database with forest and drainage studies. JAWRA, 52(5), 1275-1279. https://doi.org/10.1111/1752-1688.12438

Harmel, D., Qian, S., Reckhow, K., \& Casebolt, P. (2008). The MANAGE database: Nutrient load and site characteristic updates and runoff concentration data. J. Environ. Qual., 37(6), 2403-6. https://doi.org/10.2134/jeq2008.0079

Helmers, M. J., Zhou, X., Baker, J. L., Melvin, S. W., \& Lemke, D. W. (2012). Nitrogen loss on tile-drained Mollisols as affected by nitrogen application rate under continuous corn and cornsoybean rotation systems. Canadian J. Soil Sci., 92(3), 493-499. https://doi.org/10.4141/Cjss2010-043

Hertzberger, A., Pittelkow, C. M., Harmel, R. D., \& Christianson, L. E. (2019). The MANAGE drain concentration database: A new tool compiling North American drainage nutrient concentrations. Agric. Water Mgmt., 216, 113-117. https://doi.org/10.1016/j.agwat.2019.01.021

IEPA. (2015). Illinois nutrient loss reduction strategy. Springfield, IL: Illinois Environmental Protection Agency. Retrieved from https://www2.illinois.gov/epa/topics/water-quality/watershedmanagement/excess-nutrients/Pages/nutrient-loss-reductionstrategy.aspx

ISU. (2017). Iowa nutrient reduction strategy. Ames, IA: Iowa State University. Retrieved from http://www.nutrientstrategy.iastate.edu/

ISU. (2019). Iowa State University corn N rate calculator. Ames, IA: Iowa State University. Retrieved from http://cnrc.agron.iastate.edu/

Jaynes, D. B. (2013). Nitrate loss in subsurface drainage and corn yield as affected by timing of sidedress nitrogen. Agric. Water Mgmt., 130, 52-60. https://doi.org/10.1016/j.agwat.2013.08.010

Jaynes, D. B., \& Colvin, T. S. (2006). Corn yield and nitrate loss in subsurface drainage from midseason nitrogen fertilizer application. Agron. J., 98(6), 1479-1487. https://doi.org/10.2134/agronj2006.0046

Jaynes, D. B., Colvin, T. S., Karlen, D. L., Cambardella, C. A., \& Meek, D. W. (2001). Nitrate loss in subsurface drainage as affected by nitrogen fertilizer rate. J. Environ. Qual., 30(4), 1305-1314. https://doi.org/10.2134/jeq2001.3041305x

Kanwar, R. S., Baker, J. L., \& Baker, D. G. (1988). Tillage and split $\mathrm{N}$-fertilization effects on subsurface drainage water quality and crop yields. Trans. ASAE, 31(2), 453-461. https://doi.org/10.13031/2013.30730

Kaspar, T. C., Jaynes, D. B., Parkin, T. B., \& Moorman, T. B. (2007). Rye cover crop and gamagrass strip effects on $\mathrm{NO}_{3}$ concentration and load in tile drainage. J. Environ. Qual., 36(5), 1503-1511. https://doi.org/10.2134/jeq2006.0468

Kladivko, E. J., Frankenberger, J. R., Jaynes, D. B., Meek, D. W., Jenkinson, B. J., \& Fausey, N. R. (2004). Nitrate leaching to subsurface drains as affected by drain spacing and changes in crop production system. J. Environ. Qual., 33(5), 1803-1813. https://doi.org/10.2134/jeq2004.1803

Lawlor, P. A., Helmers, M. J., Baker, J. L., Melvin, S. W., \& Lemke, D. W. (2008). Nitrogen application rate effect on nitratenitrogen concentration and loss in subsurface drainage for a corn-soybean rotation. Trans. ASABE, 51(1), 83-94. https://doi.org/10.13031/2013.24229

Lawlor, P. A., Helmers, M. J., Baker, J. L., Melvin, S. W., \& Lemke, D. W. (2011). Comparison of liquid swine manure and aqua-ammonia nitrogen application timing on subsurface drainage water quality in Iowa. Trans. ASABE, 54(3), 973-981. https://doi.org/10.13031/2013.37121 
Leisenring, M. A., Clary, J., Strecker, E., \& Jones, J. (2016). The agricultural BMP database: A growing repository of field performance data. Proc. 10th Intl. Drainage Symp. Conf. ASABE Paper No. 162493032. St. Joseph, MI: ASABE.

Liu, W., Youssef, M. A., Birgand, F. P., Chescheir, G. M., Tian, S., \& Maxwell, B. M. (2020). Processes and mechanisms controlling nitrate dynamics in an artificially drained field: Insights from high-frequency water quality measurements. Agric. Water Mgmt., 232, 106032. https://doi.org/10.1016/j.agwat.2020.106032

Mair, P., \& Wilcox, R. (2019). Robust statistical methods in R using the WRS2 package. Behav. Res. Methods, 52, 464-488. https://doi.org/10.3758/s13428-019-01246-w

Mamo, M., Malzer, G. L., Mulla, D. J., Huggins, D. R., \& Strock, J. (2003). Spatial and temporal variation in economically optimum nitrogen rate for corn. Agron. J., 95(4), 958-964. https://doi.org/10.2134/agronj2003.9580

Marshall, E., Aillery, M., Ribaudo, M., Key, N., Sneeringer, S., Hansen, L., ... Riddle, A. (2018). Reducing nutrient losses from cropland in the Mississippi/Atchafalaya River basin: Cost efficiency and regional distribution. Washington, DC: USDA Economic Research Service. https://doi.org/10.22004/ag.econ.277567

Merriman, K. R., Gitau, M. W., \& Chaubey, I. (2009). A tool for estimating best management practice effectiveness in Arkansas. Appl. Eng. Agric., 25(2), 199-213. https://doi.org/10.13031/2013.26333

Morris, T. F., Murrell, T. S., Beegle, D. B., Camberato, J. J., Ferguson, R. B., Grove, J., ... Yang, H. (2018). Strengths and limitations of nitrogen rate recommendations for corn and opportunities for improvement. Agron. J., 110(1), 1-37. https://doi.org/10.2134/agronj2017.02.0112

NASS. (2019). Quick Stats. Washington, DC: USDA National Agriculture Statistics Service. Retrieved from https://data.nal.usda.gov/dataset/nass-quick-stats

NASS. (2020). Acreage. Washington, DC: USDA National Agriculture Statistics Service.

Nguyen, H. Q., Kanwar, R. S., Hoover, N. L., Dixon, P., Hobbs, J., Pederson, C., \& Soupir, M. L. (2013). Long-term effects of poultry manure application on nitrate leaching in tile drain water. Trans. ASABE, 56(1), 91-101. https://doi.org/10.13031/2013.42593

Ni, X., Yuan, Y., \& Liu, W. (2020). Impact factors and mechanisms of dissolved reactive phosphorus (DRP) losses from agricultural fields: A review and synthesis study in the Lake Erie basin. Sci. Total Environ., 714, 136624. https://doi.org/10.1016/j.scitotenv.2020.136624

NRCS. (2019). Nutrient management, Code 590. In National handbook of conservation practices. Washington, DC: USDA Natural Resources Conservation Service.

Oquist, K. A., Strock, J. S., \& Mulla, D. J. (2007). Influence of alternative and conventional farming practices on subsurface drainage and water quality. J. Environ. Qual., 36(4), 1194-1204. https://doi.org/10.2134/jeq2006.0274

R Development Core Team (2011). R: A language and environment for statistical computing. Vienna, Austria: R Foundation for Statistical Computing.

Randall, G. W., \& Mulla, D. J. (2001). Nitrate nitrogen in surface waters as influenced by climatic conditions and agricultural practices. J. Environ. Qual., 30(2), 337-344. https://doi.org/10.2134/jeq2001.302337x

Randall, G. W., \& Vetsch, J. A. (2005). Nitrate losses in subsurface drainage from a corn-soybean rotation as affected by fall and spring application of nitrogen and nitrapyrin. J. Environ. Qual., 34(2), 590-597. https://doi.org/10.2134/jeq2005.0590
Randall, G. W., Iragavarapu, T. K., \& Schmitt, M. A. (2000). Nutrient losses in subsurface drainage water from dairy manure and urea applied for corn. J. Environ. Qual., 29(4), 1244-1252. https://doi.org/10.2134/jeq2000.00472425002900040031x

Randall, G. W., Vetsch, J. A., \& Huffman, J. R. (2003a). Corn production on a subsurface-drained mollisol as affected by time of nitrogen application and nitrapyrin. Agron. J., 95(5), 12131219. https://doi.org/10.2134/agronj2003.1213

Randall, G. W., Vetsch, J. A., \& Huffman, J. R. (2003b). Nitrate losses in subsurface drainage from a corn-soybean rotation as affected by time of nitrogen application and use of nitrapyrin. $J$. Environ. Qual., 32(5), 1764-1772. https://doi.org/10.2134/jeq2003.1764

Rejesus, R. M., \& Hornbaker, R. H. (1999). Economic and environmental evaluation of alternative pollution-reducing nitrogen management practices in central Illinois. Agric. Ecosyst. Environ., 75(1), 41-53. https://doi.org/10.1016/S01678809(99)00058-4

Ribaudo, M., Delgado, J., Hansen, L., Livingston, M., Mosheim, R., \& Williamson, J. (2011). Nitrogen in agricultural systems: Implications for conservation policy. Washington, DC: USDA Economic Research Service. https://doi.org/10.2139/ssrn.2115532

Ruffatti, M. D., Roth, R. T., Lacey, C. G., \& Armstrong, S. D. (2019). Impacts of nitrogen application timing and cover crop inclusion on subsurface drainage water quality. Agric. Water Mgmt., 211, 81-88. https://doi.org/10.1016/j.agwat.2018.09.016

Sawyer, J., \& Barker, D. (2017). Seasonal and rotational influences on corn nitrogen fertilization in northwest Iowa. Ames, IA: Iowa State University. https://doi.org/10.31274/farmprogressreports180814-1688

Sawyer, J. E., Nafziger, E., Randall, G., Bundy, L., Rehm, G., \& Joern, B. (2006). Concepts and rationale for regional nitrogen rate guidelines for corn. Ames, IA: Iowa State University Extension and Outreach. Available at https://store.extension.iastate.edu/product/ 12240

Sela, S., van Es, H. M., Moebius-Clune, B. N., Marjerison, R., \& Kneubuhler, G. (2018). Dynamic model-based recommendations increase the precision and sustainability of $\mathrm{N}$ fertilization in midwestern U.S. maize production. Comput. Electron. Agric., 153, 256-265. https://doi.org/10.1016/j.compag.2018.08.010

Shepard, R. (2005). Nutrient management planning: Is it the answer to better management? J. Soil Water Cons., 60(4), 171-176.

Strock, J. S., Sands, G. R., \& Helmers, M. J. (2011). Subsurface drainage design and management to meet agronomic and environmental goals. In J. L. Hatfield \& T. J. Sauer (Eds.), Soil management: Building a stable base for agriculture (pp. 199208). Madison, WI: ASA-SSSA. https://doi.org/10.2136/2011.soilmanagement.c13

Sugg, Z. (2007). Assessing U.S. farm drainage: Can GIS lead to better estimates of subsurface drainage extent. Washington, DC: World Resources Institute.

Tetra Tech. (2011). User's guide: Spreadsheet tool for the estimation of pollutant load (STEPL), Ver. 4.4. Pasadena, CA: Tetra Tech, Inc.

Thoma, D. P., Gupta, S. C., Strock, J. S., \& Moncrief, J. F. (2005). Tillage and nutrient source effects on water quality and corn grain yield from a flat landscape. J. Environ. Qual., 34(3), 11021111. https://doi.org/10.2134/jeq2004.0200

USEPA. (2017). Mississippi River/Gulf of Mexico Watershed Nutrient Task Force :2017 Report to Congress. Washington, DC: U.S. Environmental Protection Agency. Retrieved from https://www.epa.gov/sites/production/files/201711/documents/hypoxia_task_force_report_to_congress_2017_fi nal.pdf 
Van Meter, K. J., Van Cappellen, P., \& Basu, N. B. (2018). Legacy nitrogen may prevent achievement of water quality goals in the Gulf of Mexico. Science, 360(6387), 427-430.

https://doi.org/10.1126/science.aar4462

Wickham, H. (2011). ggplot2. WIREs Comput. Stat., 3(2), 180-185. https://doi.org/10.1002/wics.147

Wickham, H., Francois, R., Henry, L., \& Muller, K. (2015). dplyr: A grammar of data manipulation. Retrieved from https://cran.rproject.org/web/packages/dplyr/index.html

\section{NOMENCLATURE}

ACPs = agricultural conservation practices

AgBMPDB = Agricultural BMP Database

ANOVA $=$ analysis of variance

BMPs $=$ best management practices

MANAGE = Measured Annual Nutrient loads from Agricultural Environments database

$\left[\mathrm{NO}_{3}-\mathrm{N}\right]=$ nitrate- $\mathrm{N}$ concentration

$\mathrm{QA} / \mathrm{QC}=$ quality assurance and quality control

$\mathrm{UAN}=$ urea ammonia nitrate

\section{APPENDiX A}

Table A1. Summary of database sources for peer-reviewed research articles on nutrient management and water quality.

\begin{tabular}{cccc}
\hline Database & Source & Primary Selection Criteria & Count \\
\hline AgBMP database & Leisenring et al. (2016) & Studies with at least one fertilization event & 66 \\
AgCROS & Delgado et al. (2018) & Studies with water quality measurements & 4 \\
Arkansas BMP tool & Merriman et al. (2009) & Citations related to nutrient management & 3 \\
CTIC BMP & Fawecett and Smith (2009) & All the citations used in this review & 276 \\
INRS & INRS and IDNR (2017) & Citations related to nutrient management & 53 \\
MANAGE & Harmel et al. (2008, 2016) & Studies with at least one fertilization event & 146 \\
Ohio BMP factsheet & https://agbmps.osu.edu/references & All the citations used in this tool & 32 \\
STEPL & Tetra Tech $(2011)$ & All the citations used in this tool & 45 \\
\hline
\end{tabular}

Table A2. Statistical p-values for group comparisons for fertilization source, method, and split fertilization among different rate groups. Bounded values are significant at the 0.05 confidence level.

\begin{tabular}{ccccc}
\hline Response Variable & Rate Group & Source & Method & Split \\
\hline & Low & 0.008 & 0.068 & 0.079 \\
Corn yield & Moderate & 0.220 & 0.769 & 0.248 \\
& High & $<0.001$ & 0.540 & 0.337 \\
& Very high & 0.002 & 0.003 & 0.718 \\
\hline & Low & 0.008 & 0.077 & 0.826 \\
Flow-weighted & Moderate & 0.148 & 0.822 & 0.130 \\
concentrations & High & 0.027 & 0.001 & 0.508 \\
& Very high & 0.754 & 0.058 & 0.863 \\
\hline
\end{tabular}

Table A3. Statistical p-values of post-hoc tests for robust two-way ANOVA of flow-weighted concentrations in response to fertilizer rates and single versus split fertilization. Bounded values are significant at the 0.05 confidence level.

\begin{tabular}{ccccc}
\hline & $\begin{array}{c}\text { Low } \\
\text { and } \\
\text { (single } \\
\text { vs. split) }\end{array}$ & $\begin{array}{c}\text { Moderate } \\
\text { and } \\
\text { (single } \\
\text { vs. split) }\end{array}$ & $\begin{array}{c}\text { High } \\
\text { and } \\
\text { (single } \\
\text { vs. split) }\end{array}$ & $\begin{array}{c}\text { Very High } \\
\text { and } \\
\text { (single } \\
\text { vs. split) }\end{array}$ \\
\hline Low and (single vs. split) & NA & - & - & - \\
Moderate and (single vs. split) & 0.35 & NA & - & - \\
High and (single vs. split) & 0.01 & 0.01 & NA & - \\
Very high and (single vs. split) & $<0.01$ & $<0.01$ & 0.35 & NA \\
\hline
\end{tabular}

Table A4. Nitrogen fertilizer cost inputs used in cost analysis calculations (from Iowa State University Corn N Rate Calculator and USDA-NASS survey data from 2012 to 2014).

\begin{tabular}{cc} 
USDA-NASS survey data from 2012 to 2014). \\
\hline Fertilizer Type & Cost $\left(\$ \mathrm{~kg} \mathrm{~N}^{-1}\right)$ \\
\hline Anhydrous ammonia & 1.10 \\
UAN, $28 \%$ & 1.54 \\
Aqueous ammonia & 1.32 \\
Urea, $44 \%$ to $46 \%$ & 1.48 \\
\hline
\end{tabular}

Table A5. Corn grain yields used in cost analysis calculations, from synthesized literature averages for each rate group and cropping system and from the $\mathbf{N}$ rate response curve from Sawyer and Barker (2017) adjusted for the USDA-NASS national average (2016-2018).

\begin{tabular}{cccc}
\hline \multirow{4}{*}{ Cropping System } & \multicolumn{2}{c}{ Yield $\left(\mathrm{kg} \mathrm{ha}^{-1}\right)$} \\
\cline { 3 - 4 } & Rate Group & Synthesized & Adjusted \\
Data & NASS Data \\
\hline \multirow{4}{*}{ Continuous corn } & Low & 5880 & 8223 \\
& Moderate & 7521 & 9917 \\
& High & 8093 & 10733 \\
& Very high & 9042 & 11110 \\
\hline \multirow{5}{*}{ Corn-soybean } & Low & 7440 & 10922 \\
& Moderate & 9019 & 12240 \\
& High & 9564 & 12554 \\
& Very high & 10279 & 12679 \\
\hline
\end{tabular}

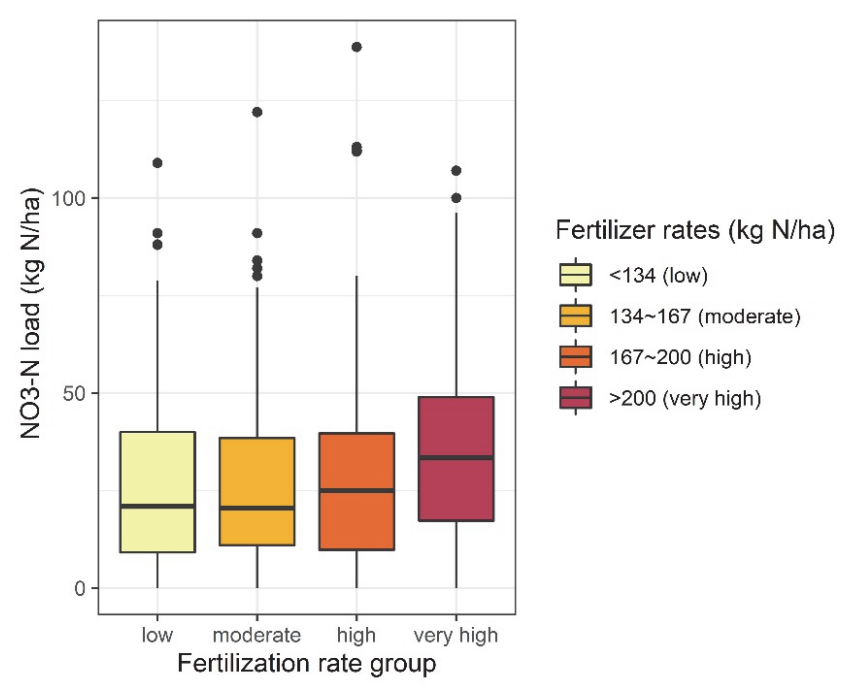

Figure A1. Drainage $\mathrm{NO}_{3}-\mathrm{N}$ loads from the synthesized literature for different fertilizer rate groups. 
Table A6. Other cost analysis input variables and their units, values, data sources, and specifications.

\begin{tabular}{|c|c|c|c|}
\hline Definition & Value & Source & Notes \\
\hline $\begin{array}{l}\text { Market price of } \\
\text { corn grain }\end{array}$ & $\$ 0.13 \mathrm{~kg}^{-1}$ & USDA-NASS, 2016-2018 & Survey, price received, Iowa \\
\hline $\begin{array}{l}\text { Market price of } \\
\text { soybean grain }\end{array}$ & $\$ 0.36 \mathrm{~kg}^{-1}$ & USDA-NASS, 2016-2018 & Survey, price received, Iowa \\
\hline Soybean yield & $3620 \mathrm{~kg} \mathrm{ha}^{-1}$ & USDA-NASS, 2016-2018 & Survey, national \\
\hline $\begin{array}{l}\text { Cost of injecting } \\
\text { fertilizer }\end{array}$ & $\$ 30.89 \mathrm{ha}^{-1}$ & 2019 Iowa Farm Custom Rate Survey & $\begin{array}{l}\text { Injecting with tool bar, includes cost of operating } \\
\text { machinery and fuel costs (assumption) but not materials. }\end{array}$ \\
\hline $\begin{array}{c}\text { Cost of liquid } \\
\text { fertilizer spraying }\end{array}$ & $\$ 18.04$ ha $^{-1}$ & 2019 Iowa Farm Custom Rate Survey & $\begin{array}{l}\text { Liquid spraying, includes cost of operating machinery } \\
\text { and fuel costs (assumption) but not materials. }\end{array}$ \\
\hline $\begin{array}{c}\text { Cost of liquid } \\
\text { fertilizer side-dress }\end{array}$ & $\$ 28.05 \mathrm{ha}^{-1}$ & 2019 Iowa Farm Custom Rate Survey & $\begin{array}{l}\text { Liquid side-dressing, includes cost of operating machinery } \\
\text { and fuel costs (assumption) but not materials. }\end{array}$ \\
\hline $\begin{array}{l}\text { Cost of dry } \\
\text { fertilizer application }\end{array}$ & $\$ 14.33 \mathrm{ha}^{-1}$ & 2019 Iowa Farm Custom Rate Survey & $\begin{array}{l}\text { Dry application, includes cost of operating machinery } \\
\text { and fuel costs (assumption) but not materials. }\end{array}$ \\
\hline $\begin{array}{l}\text { Cost of pesticides } \\
\text { for corn after corn }\end{array}$ & $\$ 195.46 \mathrm{ha}^{-1}$ & $\begin{array}{l}\text { Estimated Costs of Crop Production in } \\
\text { Iowa 2019; Illinois Crop Budget } 2019\end{array}$ & $\begin{array}{l}\text { Combined pesticides, herbicides, fungicides; assumed to } \\
\text { include cost of operating machinery, fuel costs; total } \\
\text { application over whole season. }\end{array}$ \\
\hline $\begin{array}{l}\text { Cost of pesticides } \\
\text { for corn after } \\
\text { soybean }\end{array}$ & $\$ 166.28 \mathrm{ha}^{-1}$ & $\begin{array}{l}\text { Estimated Costs of Crop Production in } \\
\text { Iowa 2019; Illinois Crop Budget } 2019\end{array}$ & $\begin{array}{l}\text { Combined pesticides, herbicides, fungicides; assumed to } \\
\text { include cost of operating machinery, fuel costs; total } \\
\text { application over whole season. }\end{array}$ \\
\hline $\begin{array}{l}\text { Cost of pesticides } \\
\text { for soybeans }\end{array}$ & $\$ 109.79$ ha $^{-1}$ & $\begin{array}{l}\text { Estimated Costs of Crop Production in } \\
\text { Iowa 2019; Illinois Crop Budget } 2019\end{array}$ & $\begin{array}{l}\text { Combined pesticides, herbicides, fungicides; assumed to } \\
\text { include cost of operating machinery, fuel costs; total } \\
\text { application over whole season. }\end{array}$ \\
\hline $\begin{array}{l}\text { Cost of seed } \\
\text { for corn }\end{array}$ & $\$ 0.003538$ seed $^{-1}$ & USDA-NASS, 2014 & Survey, price paid, $\$ 283$ for 80,000 kernels. \\
\hline $\begin{array}{l}\text { Corn seeding } \\
\text { rate }\end{array}$ & 35,000 seeds ha ${ }^{-1}$ & $\begin{array}{l}\text { https://crops.extension.iastate.edu/encyclopedia/ } \\
\text { corn-seeding-rates-and-variable-rate-seeding }\end{array}$ & - \\
\hline $\begin{array}{l}\text { Cost of planting } \\
\text { corn }\end{array}$ & $\$ 50.41 \mathrm{ha}^{-1}$ & 2019 Iowa Farm Custom Rate Survey & Planting without attachments \\
\hline $\begin{array}{l}\text { Cost of seed } \\
\text { for soybean }\end{array}$ & $\$ 0.000479$ seed $^{-1}$ & $\begin{array}{l}\text { https://www.canr.msu.edu/news/soybean } \\
\text { populations_in_30_inch_rows }\end{array}$ & $\$ 67$ for 140,000 seeds \\
\hline $\begin{array}{l}\text { Soybean seeding } \\
\text { rate }\end{array}$ & 140,000 seeds ha $^{-1}$ & Iowa State University 2013 & - \\
\hline $\begin{array}{l}\text { Cost of planting } \\
\text { soybean }\end{array}$ & $\$ 47.20 \mathrm{ha}^{-1}$ & 2019 Iowa Farm Custom Rate Survey & Drilling soybeans \\
\hline Labor costs & $\$ 127.51 \mathrm{ha}^{-1}$ & 2019 Iowa Farm Custom Rate Survey & $\begin{array}{l}\text { Includes cost for pre-harvest labor only, harvest labor } \\
\text { included in harvest cost, } \$ 12|\$ 17.20| \$ 30 \text { per hour. }\end{array}$ \\
\hline $\begin{array}{l}\text { Cash rental cost } \\
\text { for land }\end{array}$ & $\$ 574.10 \mathrm{ha}^{-1}$ & USDA-NASS, 2016-2018 & Survey, rent, cash, cropland for Iowa (for the year). \\
\hline $\begin{array}{l}\text { Cost of harvesting } \\
\text { corn }\end{array}$ & $\$ 133.68 \mathrm{ha}^{-1}$ & 2019 Iowa Farm Custom Rate Survey & $\begin{array}{l}\text { Complete harvest, includes fuel costs for equipment } \\
\text { and labor costs. }\end{array}$ \\
\hline $\begin{array}{l}\text { Cost of harvesting } \\
\text { soybean }\end{array}$ & $\$ 127.38 \mathrm{ha}^{-1}$ & 2019 Iowa Farm Custom Rate Survey & $\begin{array}{l}\text { Complete harvest, includes fuel costs for equipment } \\
\text { and labor costs. }\end{array}$ \\
\hline $\begin{array}{l}\text { Cost of soil } \\
\text { preparation }\end{array}$ & $\$ 38.05 \mathrm{ha}^{-1}$ & 2019 Iowa Farm Custom Rate Survey & $\begin{array}{c}\text { Disk tilling, tandem; assume reduced tillage, } \\
\text { once per season. }\end{array}$ \\
\hline
\end{tabular}

\section{APPENDIX B}

Because researchers generally reported annual $\mathrm{NO}_{3}-\mathrm{N}$ load and discharge as a mean for each treatment, there were some differences between our estimated and reported values of flow-weighted $\left[\mathrm{NO}_{3}-\mathrm{N}\right]$. To quantify such differences, we compared the estimated values (based on eq. 1) and the values reported by Bakhsh et al. (2002) and Lawlor et al. (2008) (fig. B1). Based on these comparisons and resulting $\mathrm{R}^{2}$ values, our estimation method provided acceptable estimations of flow-weighted $\left[\mathrm{NO}_{3}-\mathrm{N}\right]$ compared with the reported values in these original publications.

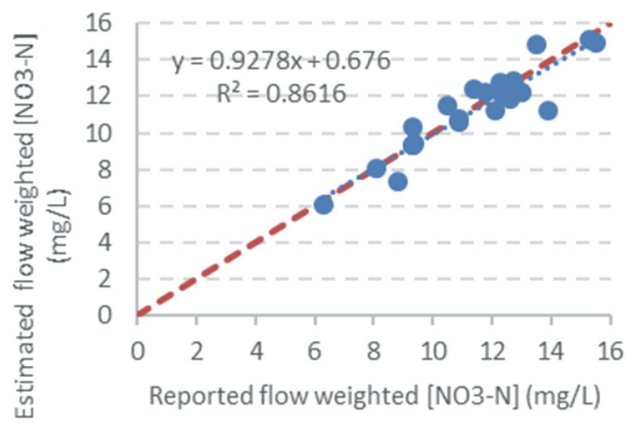

(a) Bakhsh et al. (2002)

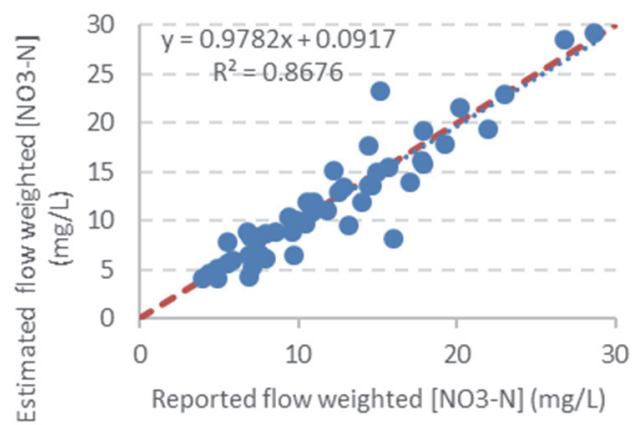

(b) Lawlor et al. (2008)

Figure B1. Comparison between estimated and reported flow-weighted [NO $3-\mathrm{N}]$ in (a) Bakhsh et al. (2002) and (b) Lawlor et al. (2008). Red dashed lines are 1:1 ratio lines. 